\title{
ヘテロ原子を含む七員環化合物の合成
}

横尾晃*

Synthesis of Seven-membered Heterocyclic Compounds.

Akira Yокоо*

ヘテロ原子を含む七員環化合物については1899～1900 年に Wallach が $\varepsilon$-カプロラクタムを，1899 年に Thiele がイミノジベンジール (10,11-dihydro,-71) 1903 年真 島先生らが (9)を, 1907 年 Thieleは（75）を合成して いるが,そのごこの方面の研究はそれほど進まなかった。 十数年前よりしだいに多くなり，特に 1961 年 Hoffmann-La Roche の Sternbach らが (65) のような化合物を 合成し，すぐれた精神安定剤として使用されるようにな ってから急速に報告が多くなった。1958年頃までの総説 としては P.M. Malitlis*) が書いている。

ヘテロ七員環の基本になる名前をつぎにあげておく。 しかし (1)，(7) などはその誘導体のみが合成されてい る。

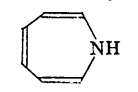

arepine (1)

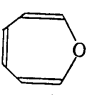

oxepin (2)

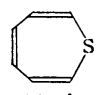

thiepin(3)

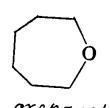

axepane (5)

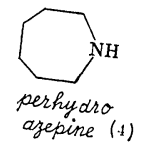

thiepane

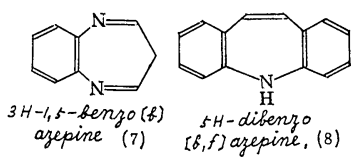

(Iminostilbene)

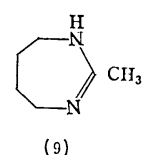

(9)

\section{I. 炭素環化合物亡同じ一般的な方法による合成}

1. オキシムのペックマン転位による合成 良く知 られているようにナイロン 6 合成原料である $\varepsilon$-カプロ ラクタム合成で代表される反応で, シクロヘキサノンオ キシムを漂硫酸, リン酸などで転位を行う。Wallach ${ }^{1)}$ の 方法である。つぎのように進むものと思われるが，強酸 下の転位は途中開環ニトリルを通るという Hill ら， Grob') らの説もある。

* 岡山大学理学部 (岡山市津島)

* Fuculty of Science, Okayama, University (Thushima, Okayama)
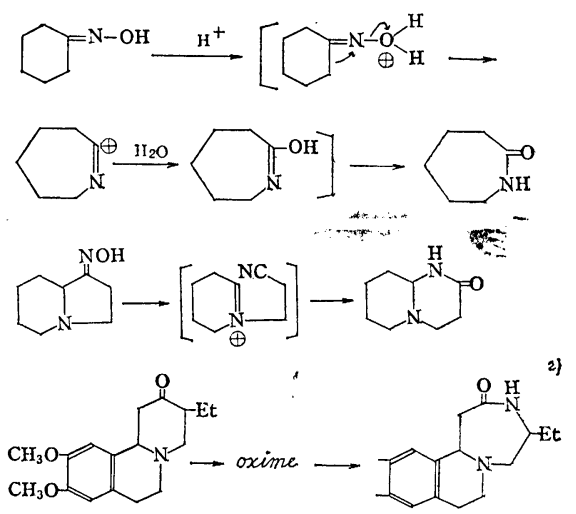

2. アジ化水素酸またはその誘導体を用いて環拡大を 行う方法この方法は Schmidt 法といわれるもので 広く行われている。

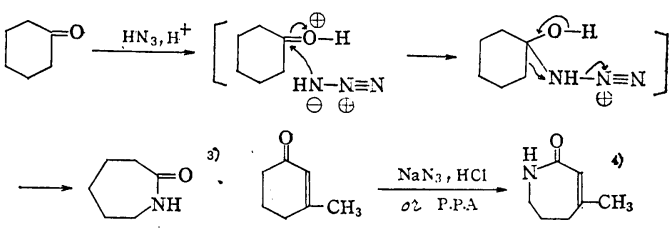<smiles>[R]C1C(=O)C([R])C([R])C([R])C1=O</smiles>

$\rightarrow \underbrace{\mathrm{NH}}_{\mathrm{O}} \overbrace{\mathrm{O}}^{\mathrm{CN}} \stackrel{\mathrm{HCl}}{\longrightarrow} \mathrm{CH}_{2}\left[-\mathrm{CH}-\left(\mathrm{CH}_{2}\right)_{4} \mathrm{COOH}\right]_{2}^{1} \cdot 2 \mathrm{HCl}$<smiles>CC1CC(=O)CCN1C</smiles><smiles>O=C1NCN2c3ccccc3Sc3cccc(c32)N1</smiles> 
<smiles>CN1CCC(O)C2CCCCC2C1</smiles><smiles>CN1CC2C[C@H](C1)O2</smiles>

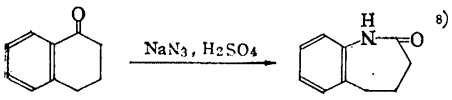

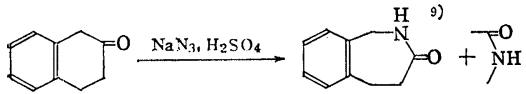

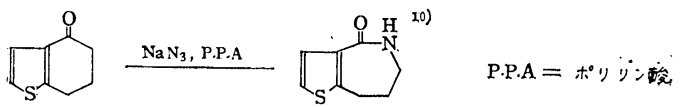

Hafner らによると， ゙ンゼンなどの二重 結合をもって 决化合物に nitrene (：N-R) になるようなものを作 用させるとアゼピン誘導体 ${ }^{12}{ }^{2}$ がえられる。これからアゼ ピンをえようとしたがえられなかっだ²。

$$
D+\mathrm{N}_{3} \mathrm{COOR} \text { (: N-COOEt, ethoxycarbonylnitrene) }
$$$$
\left(\mathrm{R}=\mathrm{C}_{2} \mathrm{H}_{5}, \mathrm{t}-\mathrm{Bu}, \mathrm{Ph} \text { etc. }\right) \stackrel{\mathrm{iiAlH}_{4}}{\longrightarrow} \underset{8 \pi \mathrm{e}}{\longrightarrow} \mathrm{N}-\mathrm{CH}_{3}
$$$$
\text { 12) }
$$
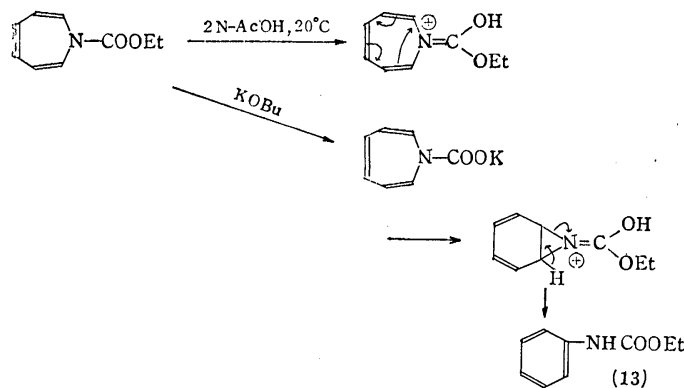

さらにトルェン，キシレン，メシチレン,デュレン,塩 化ベンゼンなどにも同様な反応をするが，メトキシ基の ような環の電子密度を大きくする置換基が入るとニトレ ンは二重結合へ付加しないで求電子反応をおこしやすく なる。アニリン，メチルアニリン，ピリジンなどでは窒 素へ求電子反応をおこし（14）などのようになるし，ナ フタリンも求電子反応をおこし，環拡大はおこらない。 また（11）の電子密度分布などを Cotter ${ }^{12)}$ が計算して いる。

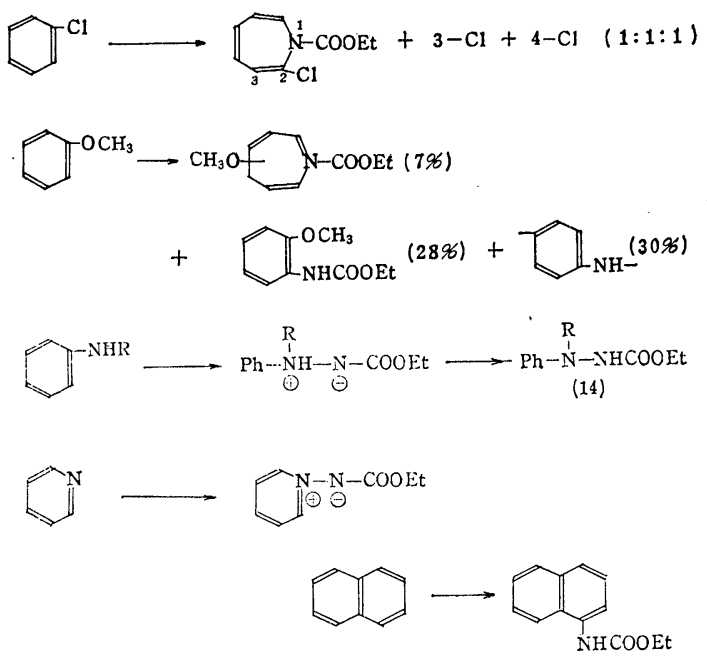

またベンゼンにシアノアジドを作用させると N-シア ノアゼピン (15) がえられることを Hafner らは最初の 報告で発表しているが，さらに Marsh ら ${ }^{13}$ は $\mathrm{N}^{15}$ を用い て好収量で合成している。(15) を酸性にすると（16） がえられることから (15) は 3,6-dimethyl-N-cyanoazepine と思われる。さらにパーフッ化ベンゼンからパー フロロシアノアゼピンをも合成している。

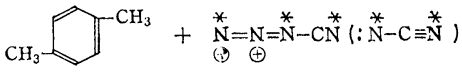

$$
\begin{aligned}
& \longrightarrow\left[2 \mathrm{CH}_{3} \leftarrow \mathrm{N}^{*}-\mathrm{CN}\right] \longrightarrow \mathrm{c}_{\substack{* \\
\mathrm{C} N^{*}}}^{*}-\mathrm{CH}_{3} \\
& \stackrel{\mathrm{H}^{+}}{\longrightarrow} \mathrm{CH}_{3}-\mathrm{CH}_{\mathrm{NHCN}}^{*}
\end{aligned}
$$

「 3. ジアゾメタンなど途中にカルベン $(: \mathrm{CHR}$ など $)$ を生じて反応すると思われるものを用いての合成

Overberger ら ${ }^{14}$ はテトラヒドロ-4-チアピロンに $\mathrm{N}-=$ トロソ-N-メチルウレタンを酸化バリウムの存在下で作 用させて 4-オクソチエパン (17) を合成している。諸 沢 ${ }^{15)}$ はN-ベンジル-4-ピペリドンから同様にして (18) を合成している。この合成はジアゾメタンではうまく行 かない。しかし Leonard ら ${ }^{14)}$ はジアゾメタンを用いて (17）を合成している。
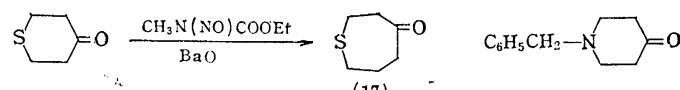
$\longrightarrow \mathrm{C}_{6} \mathrm{H}_{5} \mathrm{CH}_{2}-\mathrm{N}^{\mathrm{O}}$ (18) $\stackrel{\mathrm{H}_{2} / \mathrm{Pt} \text { or } \mathrm{Pd}}{\longrightarrow} \mathrm{HN}=\mathrm{O}$

(18)

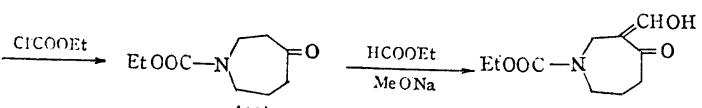

(19)

$\stackrel{\mathrm{NH}_{2} \mathrm{NHR}}{\longrightarrow}$

(19) $\frac{1 \cdot \mathrm{NBS}}{2 \cdot \mathrm{CH}_{3}-\mathrm{C}_{\mathrm{S}}^{-\mathrm{NH}_{2}}} \mathrm{EtOOC}$
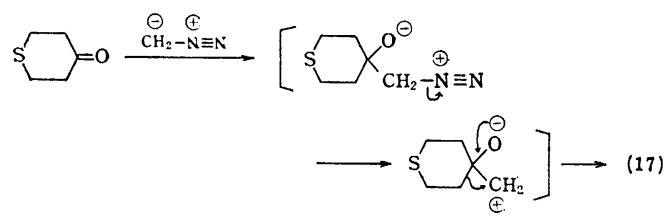

つぎに直接拡大ではないが Vogel ら ${ }^{17)}$ はブタジェン
Stogryn ら ${ }^{19)}$ は（24）の反応を利用してつぎの（25, 26）合成している。

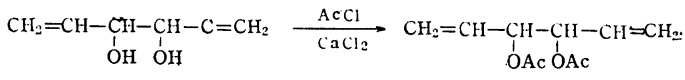

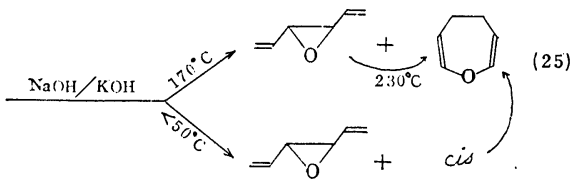

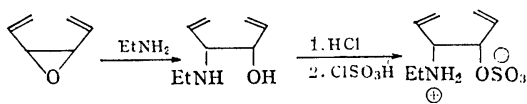

$\left.\stackrel{\alpha q \cdot \mathrm{NaOH}}{\longrightarrow}\left[\sum_{\substack{N \\ \mathrm{Et}}}\right\rangle\right]$

またつぎのようにジクロルカルベンの反応と思われる 合成法で（27）と（28）の合成も報告されている。

にジアゾ酢酸エチル（エトキシカルボ ニルカルベンとして）を作用させてで きた（20), (21) からつぎのような 2 , 3-ジヒドロ-2(3H)-オクソーアゼピン （22）をえている。そのメチル化合物 の式は N.M.R. などにより (23) であ

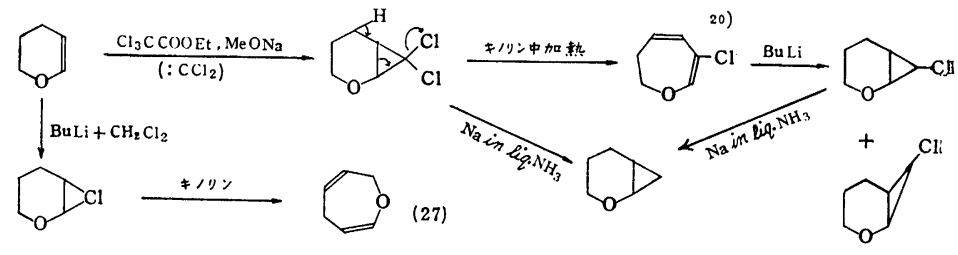
ることを推定している。
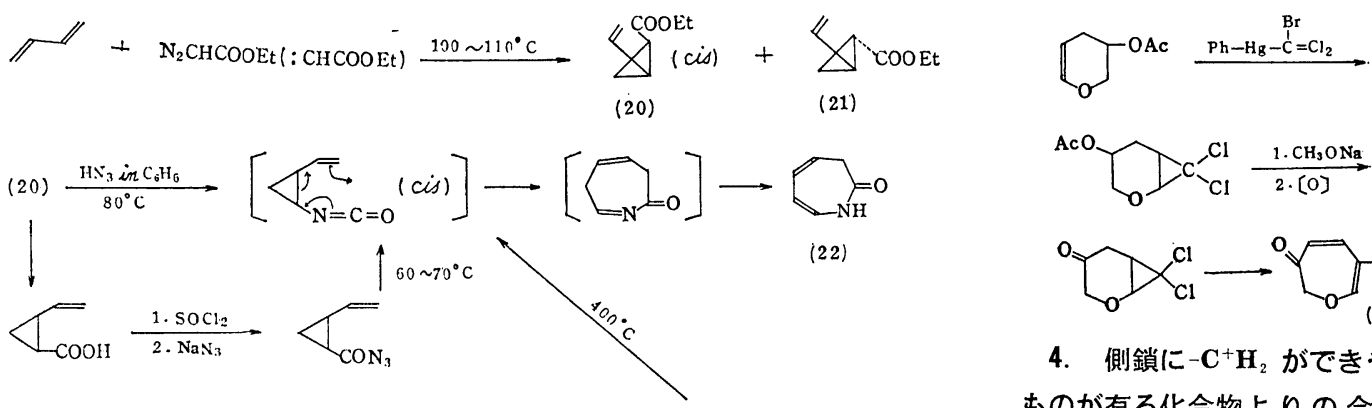

$(21) \longrightarrow \Delta \cdot \mathrm{COOH} \longrightarrow \Delta \cdot{ }^{\prime} \mathrm{CONH}_{2} \longrightarrow \Delta_{\mathrm{N}=\mathrm{C}=\mathrm{O}}$

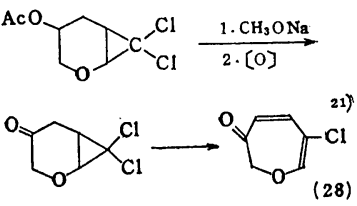

4. 側鎖に- $\mathbf{C}^{+} \mathbf{H}_{2}$ ができやすい ものが有る化合物よりの合成

Bullock ら 22) は (29) にシアン化カ リを作用させると (31) と (32)に，

（31）に酢酸中で亜硝酸ソーダを作用させると（32）に， （29）に水酸化カリを作用させても（32）になると報告し ている。後者は Benary ${ }^{24)}$ が前に (29) とシアン化カ!

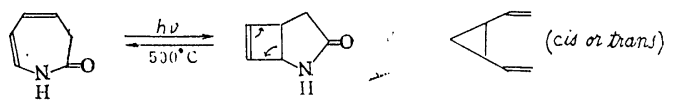

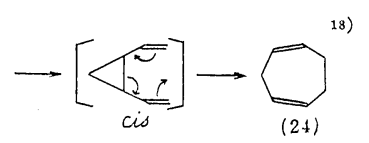
からえて、末知物質と報告していたものである。Bullock はそのご N.M.R. などにより（32）式を(33) 式に訂正 し，その機構も説明している。Brignell ら ${ }^{23)}$ は (29) シ アン化カリを作用させて（31）を合成し，最近 KCN に 対する機構をつぎのように説明している25)。(20)にシ アン化カリを作用させるとすぐ（31）になるので，まず 
(30) ができそそれに KCN が作用して（31）になると 考えている。
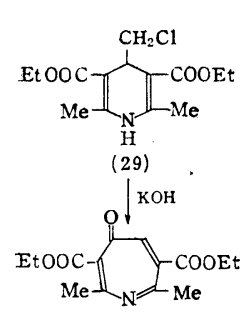

(32)

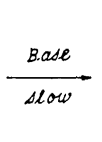

$$
\text { (20) }
$$

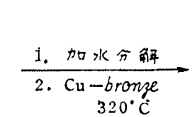
$320^{\circ} \mathrm{C}$

320
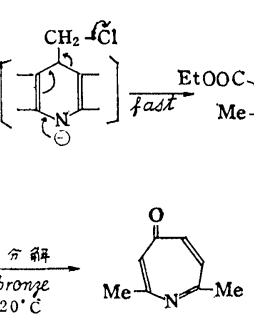

(34)

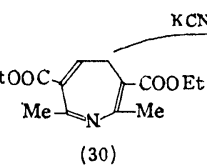

(30)

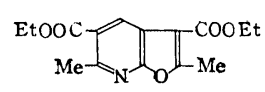

(33)
その機構は報告されていないが（41）から（46）のよ らな七員環カルボニウムイオンができてから，実線のよ

うに 2 と 5 位が結合すると （42）になるし，点線のよ うに 1 位の窒素と 5 位が結 合し, 6,7 の炭素鎖が切れ ると (43) とアセ卜酢酸メ チルになるものと思われ る。また (42) で2,3位の 部分（これは（46）で 6,7 位に相当) が離れ，1,4 位
Brignell の初報ののち Johnson ら ${ }^{26)}$ は（29）のナト リウムエトキサイドに対する反応をくわしく報告してい る。生じた（37）については N.M.R. で式を推定して いる。さらに (29) や (36) に水酸化ナトリウムを作用 させると（39）が生じ，(36)，(37）を接触還元して生じ た（38）に水酸化カリを作用させると（40）が生ずるこ とを報告している。
が結合し 4,7 位が切れると（43）になるものと思われ る。(42) で 5,6 位の鎖が光で切れると（44）になり, 1,7位の間で切れると（45) になるものと思われる。(45) は共役系の分子内塩として一応安定な形をとっているら しくカセイカリでは $=\stackrel{\oplus}{\mathrm{N}} \mathrm{HCH}_{3}$ が $=\mathrm{OH}$ になるし, ま た逆もゆく。

Moore ら ${ }^{27)}$ は (47) を合成し，これが微量の酢酸で5-

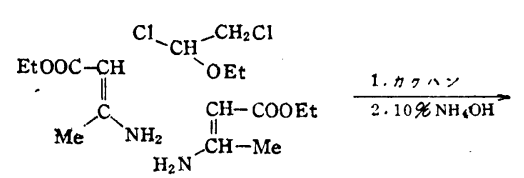

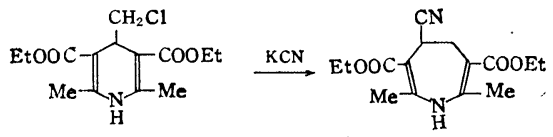

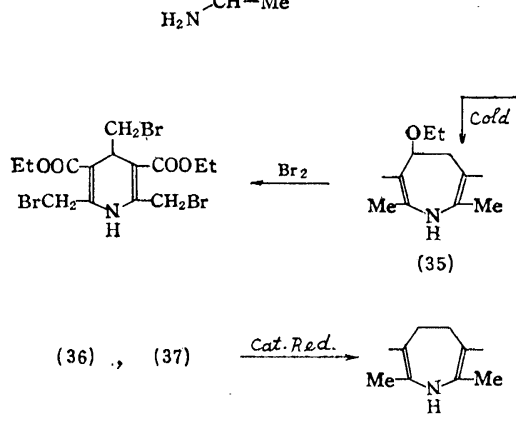

(38)

\section{(29)}

(39)
(31)

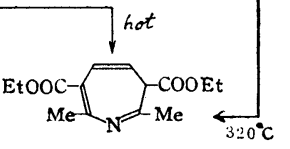

(37)<smiles>CC(=O)N1CCCC1C</smiles>

(40)

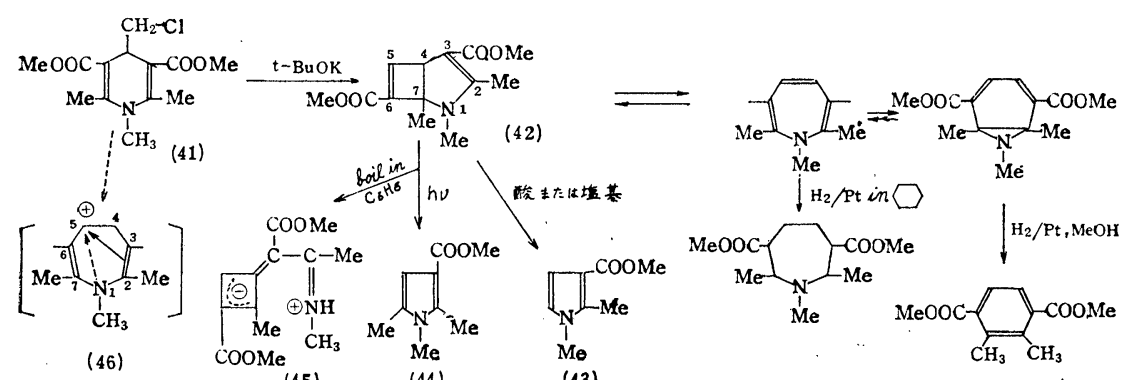

(44)

(43) 
methyl-6-phenyl-1, 2-diazepin-4(3H)-one (49) になる

ことおよびその分解反応を色々報告している。

$$
\mathrm{C}_{6} \mathrm{H}_{5} \mathrm{CH}=\mathrm{C}-\mathrm{COCl} \stackrel{\mathrm{CH}_{2} \mathrm{~N}_{2}}{\longrightarrow}[\mathrm{Ph}-\mathrm{Cll}=\mathrm{C}-\mathrm{CO}-\mathrm{CHN} 2]
$$

$\stackrel{\mathrm{CH}_{2} \mathrm{~N}_{2}}{\longrightarrow} \overbrace{\mathrm{N}=\mathrm{N}}^{\mathrm{Ph}}{ }_{(47)}^{\mathrm{CH}_{3}} \stackrel{-\mathrm{COCHN}_{2}}{\longrightarrow} \mathrm{OH}^{-}{ }^{\mathrm{Ph}} \underbrace{\mathrm{CH}_{3}}_{\mathrm{N}^{\mathrm{NH}}} \mathrm{COCHN}_{2}$

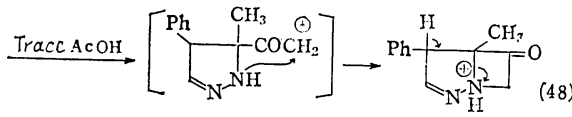

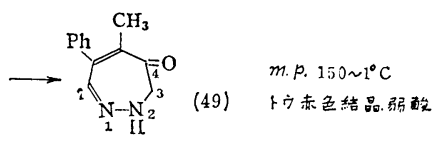

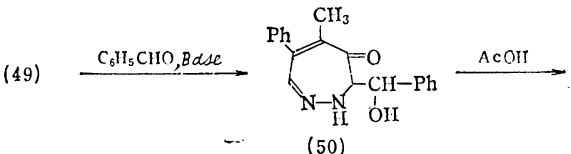

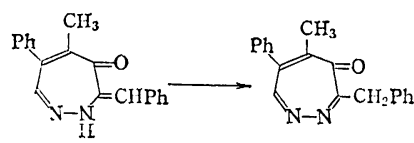

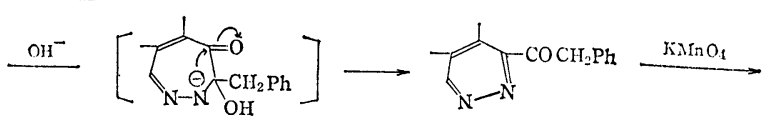

（49）をピリジン中でベンゾイル化し，酸性にすると （56）になるし，ベンゾイル化後重曹で分解すると（57） になることから途中に，(49）を合成するときの（48）に 似たものを考えている。

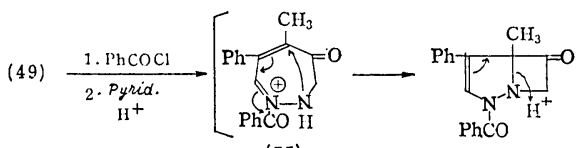

(55)

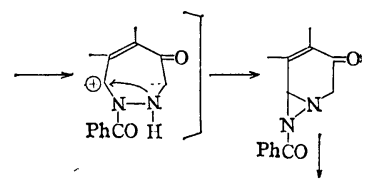

(56)

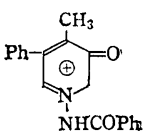

(55)

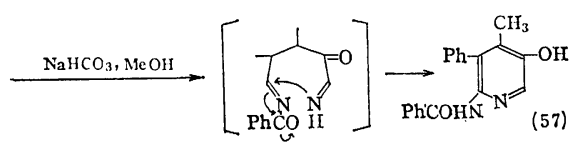

Moore ら ${ }^{28}$ はさらに(58) は酸で （59）になり，(56)，(49）に過酸化水 素を作用させると（60）になること や，光に対する反応などを報告して

（50）は最初ベンズアルデヒドが 7 位に入ったものと 考えていたが，脱水されることや N.M.R. で $\mathrm{C}_{7}$ のHが $6.99 \mathrm{ppm}(\mathrm{S})$ にあ ること， $\mathrm{C}_{3}$ のHが $3.35,3.47 \mathrm{ppm}$ にあり >CHOH のHとカップリングして 2 本になって いること， $\mathrm{CH}_{2}$ のものが無いことから 3 位に入った (50) 式住訂正している。(49) の重水中で， $\mathrm{NaOD}$ の存 在での N.M.R. の面積測定より $\mathrm{C}_{3} \mathrm{H}_{2} \rightarrow \mathrm{C}_{3} \mathrm{D}_{2}$ の方が $\mathrm{C}_{7} \mathrm{H}$ $\rightarrow \mathrm{C}_{7} \mathrm{D}$ になるより速いことなどからアルカリ中では (51), (51') になりやすく，特に (51) イオンになりやす いらしい。(49) にアルカリを作用させると（52), (53) ができ，酸では (54) ができる。

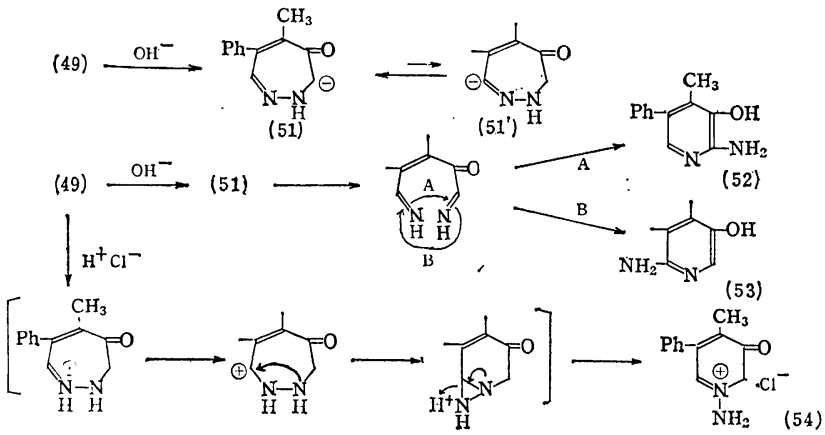

いる。さらに今年になり (61), (62), (63) などができる 反応を報告している。

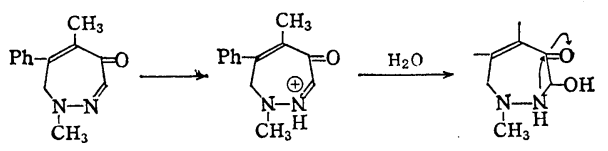

(58)

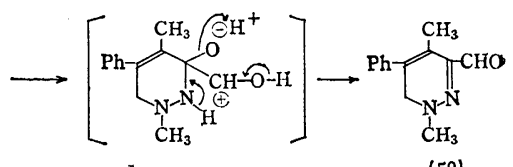

(59)
(49)
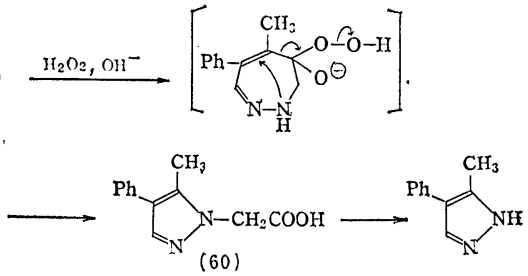


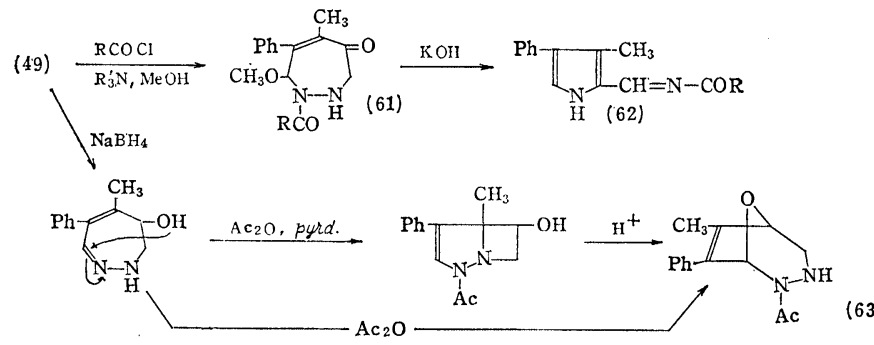

(67)のような anti オキシムが途中で出来 るが，速かに七員環になってしまうのであ ろうといっている。(64)にメチルアミン の作用については述べていないが，アルカ リと同じと考えても説明がつく。しかしつ ぎのように環が開かないで直接環拡大がお こるとも考えられる。
Sternbach ら ${ }^{29)}$ は 2-アミノベンゾフェノン誘導体の オキシムから 2-クロルキナゾリン誘導体 (64) を合成 し，それにメチルアミンや水酸化ナトリウムを反応させ て好収量でベンゾジアゼピン誘導体 $(65,66)$ などをえて いる。これについて，ここでは一例ずつをあげておく。
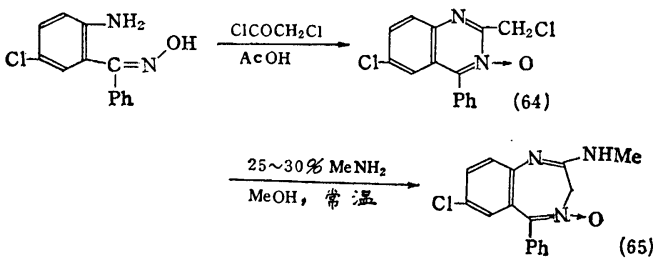

(64)

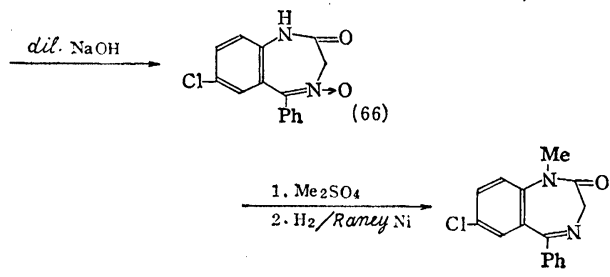

さらに最近 ${ }^{30)}(64)$ の側鎖が $\mathrm{CHCl}_{2}$ のものについて 機構を説明している。(64) についても同じように進む ものと考えられる。

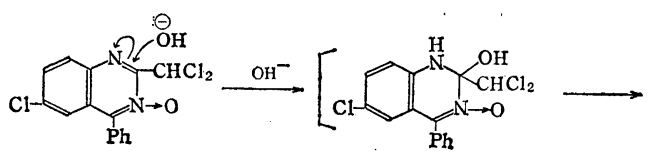

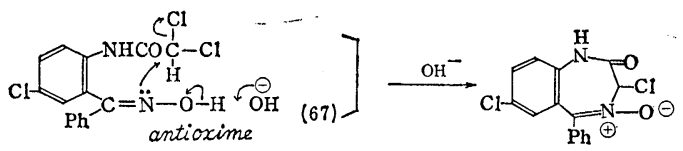

この反応には 2 当量の水酸イオンが必要であり, 上記 のように（64）功好収量で（66）になるし，また anti オキシムから直接（66）が好収量でえられるが (64) か ら anti オキシムはえられない。しかし側鎖がメチルに なった (68) からは簡単に anti オキシム (69) がえら れる。これは側鎖がメチル基であるため七員環になるこ とが出来ないのである。このことは（64）から環が開き

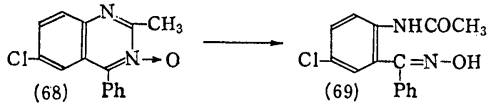

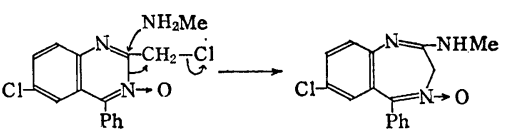

Bergmann $^{31)}$ は (70) をポリリン酸で環拡大して $5 \mathrm{H}-$ dibenzo[b, f]azepine (71) を合成した。

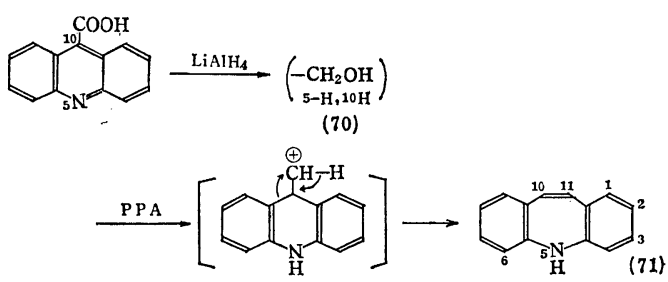

さらに dibenzo[b,f]thiepine（72）などをも合成して いる。

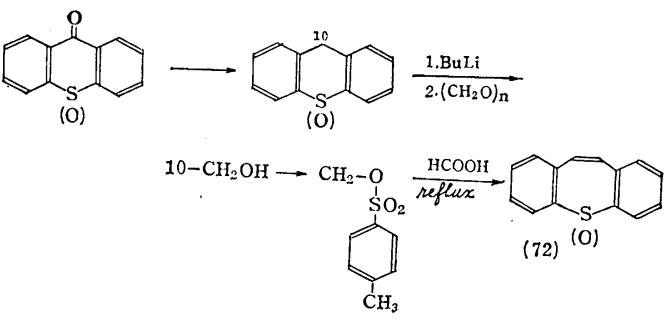

5. 1,2-ジアミノ化合物と 1,4-ジケトンなどの 縮 合 による合成 Hinsberg ${ }^{32)}$ は 1895 年 (73) を合成, Thiele $ら^{33}$ は 1907 年 $o$-フェニレンジアミン (74) とア セチルアセトンなどから 2, 4-dimethyl-3 H-1, 5-benzo 〔b〕diazepine (75) などを合成し，さらに Haley その 他 ${ }^{34}$ により追試されている。(75) は m.p. 131 $2^{\circ} \mathrm{C}$ の 無色の結晶でモノ酸塩はアズキ色を示すがジ酸塩は無色 になる。Bartrop ら, Halford ら ${ }^{35}$ は (75) を塩酸酸性で 熱すると 2-メチルベンゾイミダゾールがえられること を, Lloyd ら ${ }^{36}$ は（75） は水と熱しても分解するが, 酸 
性メタノール中では安定であると報告している。さらに

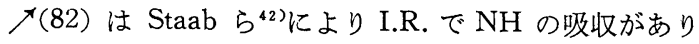
他の人により (76)のような化合物も合成されている。よ

N.M.R. で $\mathrm{NH}(2.24 \tau)$, ビニールプロトン $(5.60 \tau)$

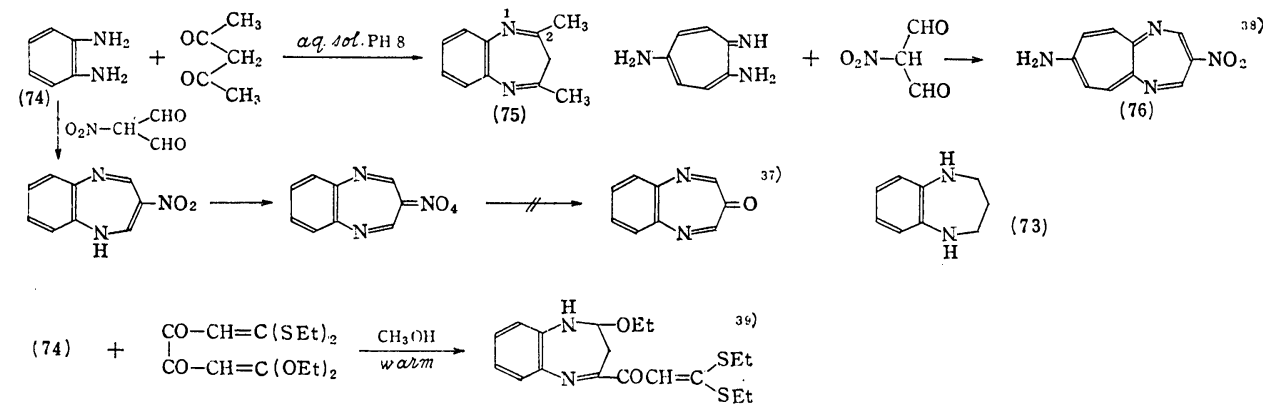

レloyd $ら^{36)}$ は (75) の合成で，これまでの人は反応は $\mathrm{pH}$ に関係するといっているが， $\mathrm{pH}$ には無関係である と報告している。Ried ら ${ }^{40)}$ は 0 -ジアミノナフタリンと アセチルアセトンとの縮合で, 1,2-ジアミノナフタリン

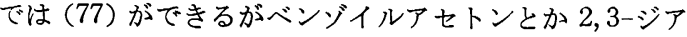
ミノナフタリンでは環を結ばず $(78,79)$ が出来ると報告 している。しかし Lloyd ら ${ }^{36)}$ は Ried らの (79) もやは り（80）のようなジアゼピン誘導体であり，縮合のとき 塩酸がないと環を結ばず（79）になるとしている。<smiles>CC1=NC2=C(N=C(C)C1)c1ccccc12</smiles><smiles>Nc1ccc2ccccc2c1N=CCCC(=O)Oc1ccccc1</smiles><smiles>COCCC(C)(C)N=C1c2ccccc2-c2ccccc21</smiles><smiles></smiles>

$\mathrm{CH}_{3} \mathrm{COCH}=\mathrm{C}\left(\mathrm{CH}_{3}\right) \mathrm{NHCH}_{2} \mathrm{CH}_{2} \mathrm{NHC}\left(\mathrm{CH}_{3}\right)=\mathrm{CHCOCH}$

(81)

またエチレンジアミンなどとアセチルアセトンなどの 縮合は Schwartzenbach ら ${ }^{41)}$, Lloyd ら ${ }^{36)} に よ り$ 行わ れているが Lloyd らはこの場合反応溶液が酸性でない と環を結ばず（81）のようなものになるといっている。 （75）でも 7 位にニト口基のような電子吸引基が入ると 環が開きやすくなる。ノ

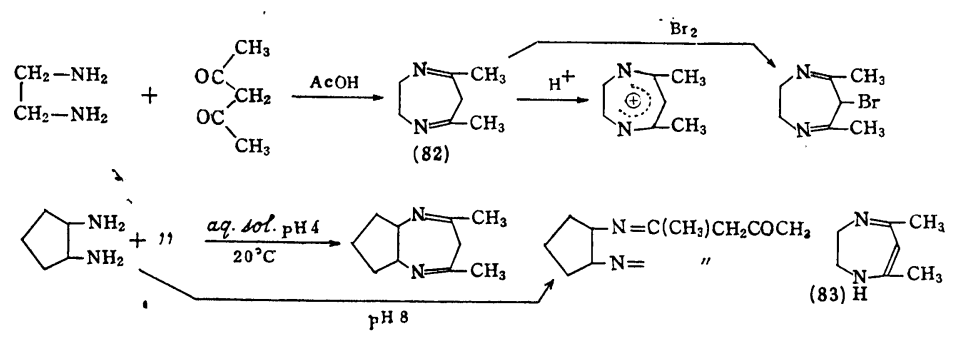

の存在することから（83）式をとっていることがわかっ た。Staab らは 1,2-ジフェニル-1,2-ジアミノェタンと アセチルアセトンを 1:1 で反応させてつぎのものをえ ているが，1：2 で反応させると環を結ばない化合物が できる。

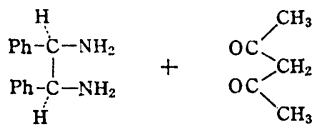

$$
\begin{aligned}
& \frac{\alpha q \text {, sol. } \mathrm{PH} 4.6}{70^{\circ} \mathrm{C}, 126 \mathrm{hr}} \underset{\mathrm{Ph}}{\mathrm{Ph}} \underset{\mathrm{H}}{2190 \mathrm{~cm}^{-1}}
\end{aligned}
$$

またつぎのように 1,2-ジアミノシクロプロパン (84) などからジアゼピン誘導体 (85) を合成している。
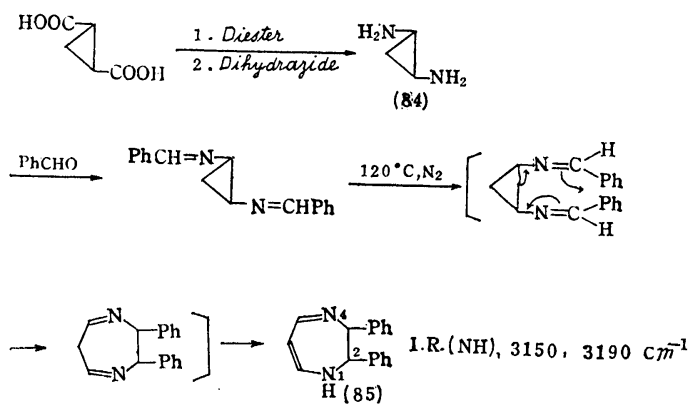

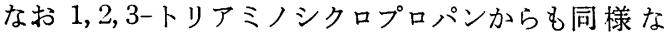
化合物ができるが，3,3-ジフェニル -1,2-ジアミノシクロプロパンから はできなかった。また Tockterma$\mathrm{nn}^{43}$ ) は前記の (75) の N.M.R.に は $\mathrm{CH}_{2}(7.30 \tau)$ が有り, ビニルプ ロトン，NH プロトンがないことか ら $\left(75^{\prime}\right)$ のような平面でない構造を とっているので無色であるが，モ， 
酸塩は平面共鳴構造をとるため着色する。しかしシ酸塩 になると共鳴構造がとれないのでまた無色になるのであ ろうと考えている。

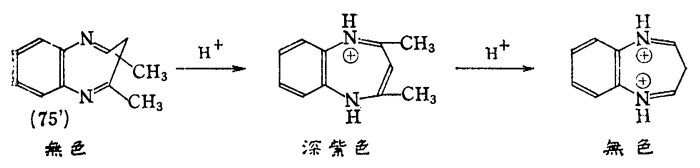

6. 1,2-ジアミノ化合物とアクリル酸エステルなどの

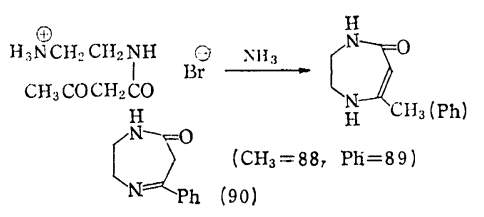

7. シシアミノ化合物を用いての，その他の合成法 これらの方法はずいぶん多いので次に式だけをあげてお く。

\section{縮合による合成この方法による合成法もかなりある}

が，その主なものをつぎに書いておく。

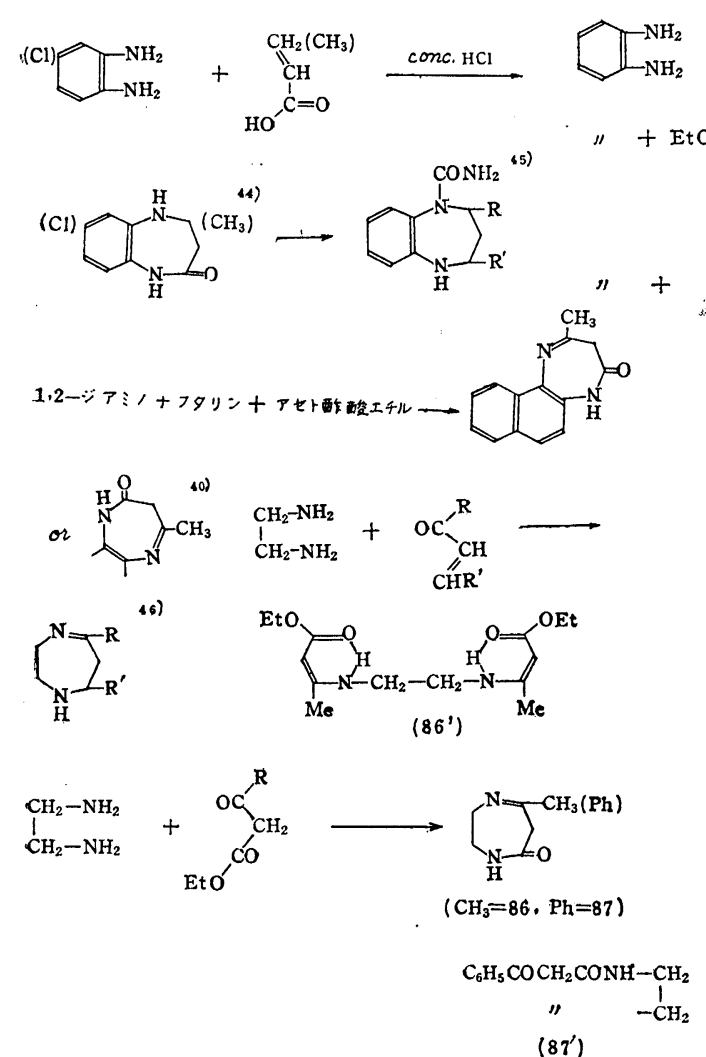

（86）は Ried ${ }^{44)}$ その他によりこの式が提出されてい たが Dudek ら ${ }^{47}$, Hofmann ら ${ }^{48}$ は I.R. でエナミンの

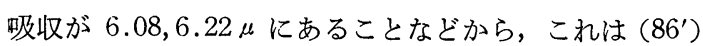
式で（87）は I.R. でカルボニル，アミドの吸収がある ことなどから $\left(87^{\prime}\right)$ 式であるとしている。また彼らは (88), (89) をも合成し，(88）は Ried らの（87）より m.p. が $35^{\circ} \mathrm{C}$ 高く, N.M.R. などでこのものは (90)よ りも（89）式をとっているといっている。

$$
\mathrm{PhCH}_{2} \mathrm{OOC}-\mathrm{NHCH}_{2} \mathrm{CH}_{2} \mathrm{NH}_{2} \frac{\begin{array}{l}
\mathrm{OC}-\mathrm{CH}_{2} \\
1 \\
\mathrm{O}-\mathrm{C}=\mathrm{CH}_{2}
\end{array}}{2 \cdot \mathrm{HBr}}
$$

$+\left(\mathrm{CH}_{2}\right)_{\mathrm{n}-1}-\mathrm{CH}_{2}-\mathrm{CO}=\mathrm{CHOH}$<smiles>CC1CCC2CCCCC2N1</smiles>
49)<smiles>COC(=O)CNC(=O)N1CCOCc2ccccc21</smiles>

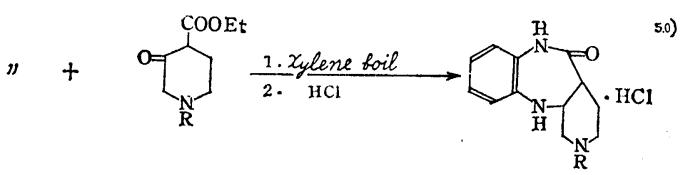

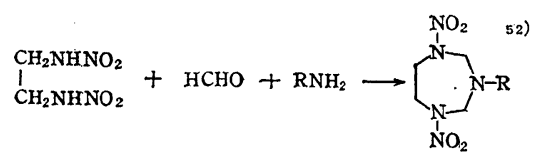

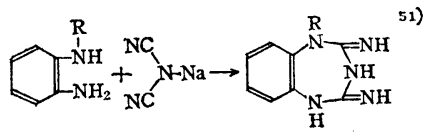

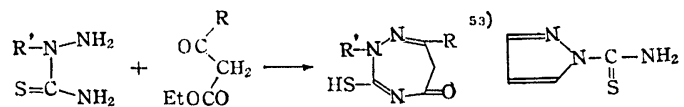

(91)

(92)

（91）は Losse らにより合成されている。この方法で （91）の 2 位に R' のない化合物は合成できないで，(92） ができる。

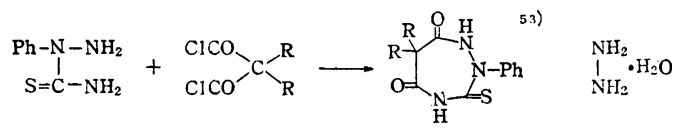

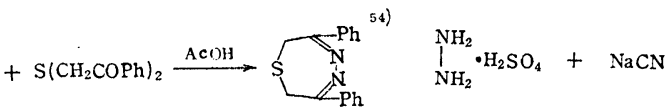

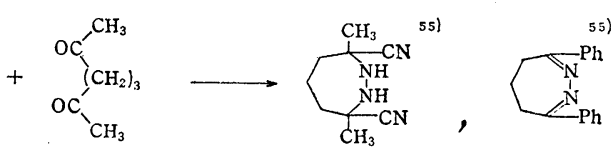




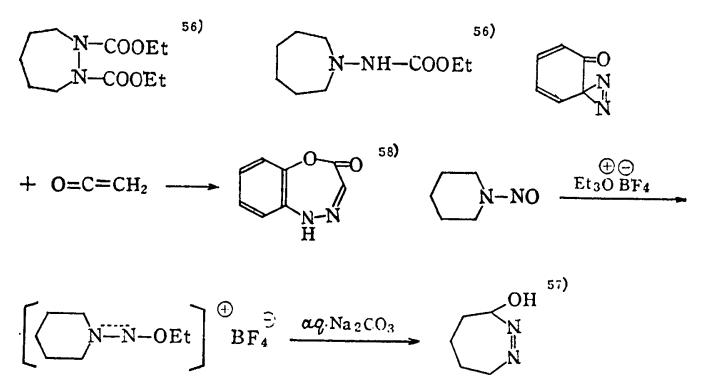

$$
\text { (S) }
$$
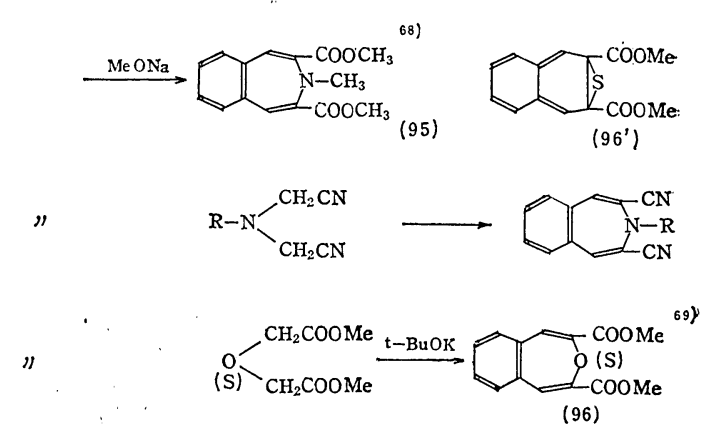

$\underbrace{\mathrm{N}}_{\mathrm{CH}_{3}} \sim_{\mathrm{CH}_{3}}^{\mathrm{CH}_{3}{ }^{59)}}$

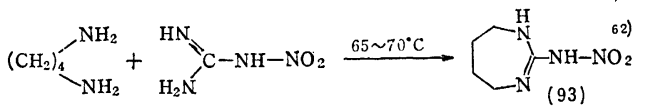

$\mathrm{P}(\mathrm{Ph})_{3}+\quad\left(\mathrm{BrCH} \mathrm{CH}_{2} \mathrm{O}-\right)_{2} \rightarrow \mathrm{Ph}_{3} \stackrel{\oplus}{\mathrm{P}}-\mathrm{CH}_{2}-\mathrm{O}-\mathrm{CH}_{2}-\stackrel{\oplus}{\mathrm{P}} \mathrm{Ph}_{3} 2 \stackrel{\ominus}{\ominus}$
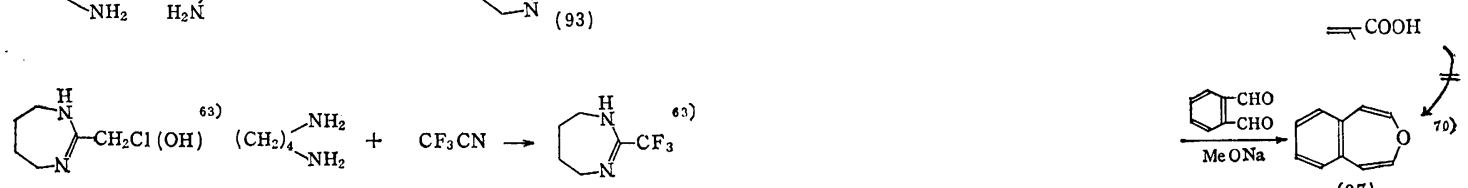

またニトロ-L-アルギニンを熱しても（93）の４位に カルボキシルの付いたものができる ${ }^{64)}$ 。

(97)

Benzothiepine 誘導体 (96) は加熱するとSがとびナ フタリン-2,3-ジカルボン酸になることが Huisgen ${ }^{71)} に$

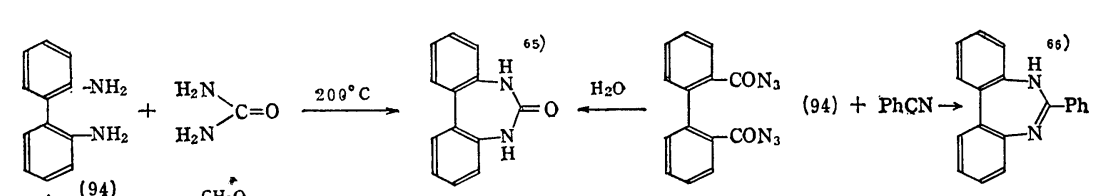
$150^{\circ} \mathrm{C} \downarrow \mathrm{RC}(\mathrm{OEt})_{3}$ or $\stackrel{(94)}{\mathrm{CH}_{3}^{\circ} \mathrm{O}} \mathrm{C}-\mathrm{R} \cdot \mathrm{HCl}$<smiles>[R]C1=Nc2ccccc2-c2ccccc2N1</smiles>

$\mathrm{R}=\mathrm{CH}_{2} \mathrm{NO}_{2}, \mathrm{CH}_{2} \mathrm{CN}, \mathrm{CH}_{2} \mathrm{COOR}^{\prime}, \mathrm{C}_{6} \mathrm{H}_{4} \mathrm{NO}_{2}(\mathrm{P}), \mathrm{Et}, \mathrm{OCH}_{3}$ etc.

より報告され， $\left(96^{\prime}\right)$ 式 の存在が考えられる。ま たHafnerらによると Fulvenoazepine 誘 導体 ${ }^{72}$, 5-azazulene $(98)^{73)}$ など も合成される。Triebs ら 74)はシュウ酸エチルとジ シアノエチルアミンとを 縮合させて（99）を合成

8. ジアミノ化合物以外 の縮合による合成法 フ タラルデヒドと N-メチルー ジーエトキシカルボニルーア ミンなどを縮合させると 3-methy1-2, 4-dimethoxycarbonyl-benzo[d]azepine （95）などが合成されるこ とを Dimroth その他が報 告している。(96) から be nzo [d] oxepine (97) はえ られないが別の方法で合成 されている。
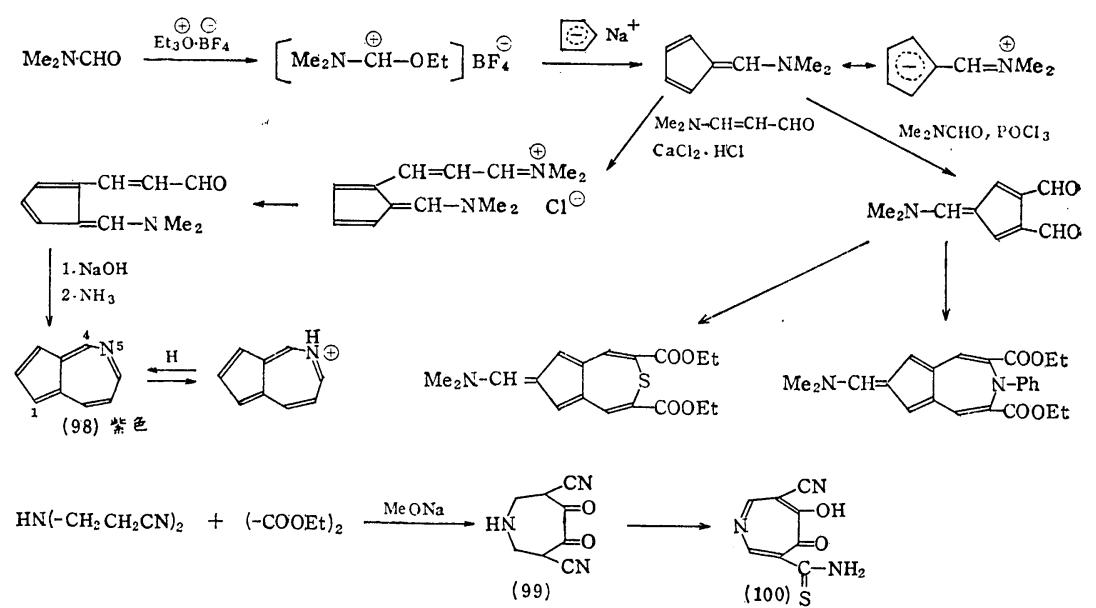


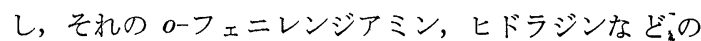
縮合物をえている。さらに (99) をイオウとキノリン中 で加熱し，アザトロポロン誘導体 (100)をキノリン塩と してえたと報告している。

しかし Rees ${ }^{75)}$ は (100) は I.R. で $\alpha, \beta$-不飽和ニト リル $(4.4 \mu)$, 飽和ニトリル $(4.5 \mu)$ があることなどか ら疑問をもち，その分解物の研究から $\left(100^{\prime}\right)$ のような 化合物であると報告している。

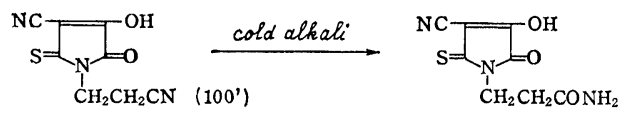

$$
\stackrel{\text { hot alkali } \longrightarrow}{\longrightarrow}=
$$

Westöö ${ }^{76)}$ は 2,5-ヘクサンジオンとシアノ酢酸アミ ドと縮合させ (101)を合成しているが，そのごその $\mathrm{HBr}$ 塩のX線解析から (102) 式に訂正している。

$$
\underset{\mathrm{CH}_{2} \mathrm{COCH}_{3}}{\mathrm{CH}_{2} \mathrm{COCH}_{3}}+\underset{\text { altali }}{\mathrm{CHNH}_{2} \mathrm{CN}}
$$

\section{Dieckmann 縮合, Friedel-Krafts 反応など}

による合成 横尾ら ${ }^{77}$ は Dieckmann 縮合により (18) を合成したが収量がわるい。最近 Casy ${ }^{77)}$ は水素化ナト リウムやフエニールリチウムなどを縮合剤として同じも のを合成している。また Astill ${ }^{78)}$ は $(103,104)$ を, Proctor $^{79)}$ は (104), Leonard ら ${ }^{80}$ は (105)を合成して いる。

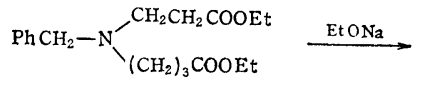

$$
\begin{aligned}
& {\left[\mathrm{PhCH}_{2}-N_{(\operatorname{lot} \operatorname{coOEt} t)}^{\mathrm{COOEt}}\right] \rightarrow \mathrm{PhCH}_{2}-N=0}
\end{aligned}
$$<smiles>CCOC(=O)CN(C)c1ccccc1C(=O)OC</smiles><smiles>CCOC(=O)CN1Cc2ccccc2CC1C(=O)OCC</smiles>
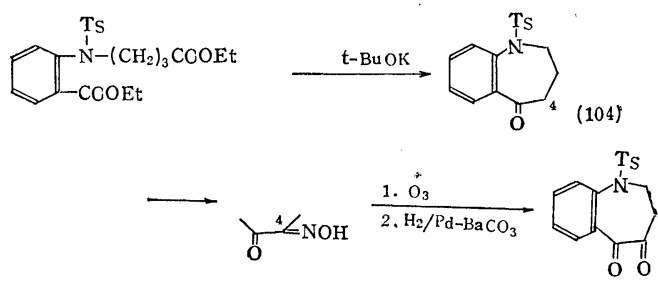

McElvain ら ${ }^{81)}$ はアシロイン縮合により 5-Hydroxy1-aza-Cycloheptan-4-one の誘導体（106）を合成し， Bell ら ${ }^{82)}$ は (107) を合成している。

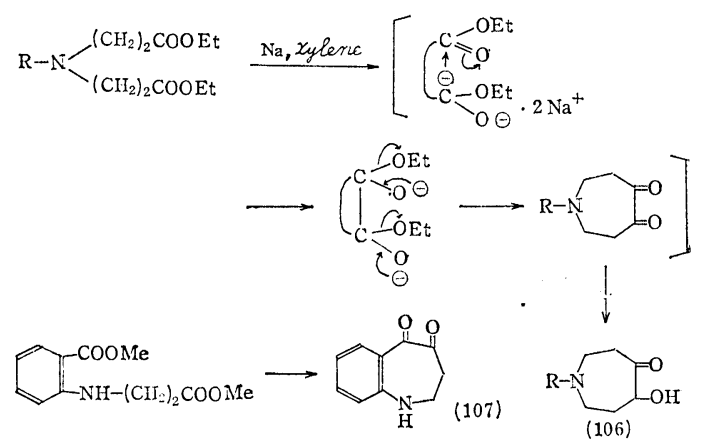

Ruggli ら ${ }^{83)}$ はジニトリルの還元的閉環により (108, 109)を Nitzschke ら ${ }^{84)}$ は (110)を，Kotelko ${ }^{85)}$ は (111) を合成している。
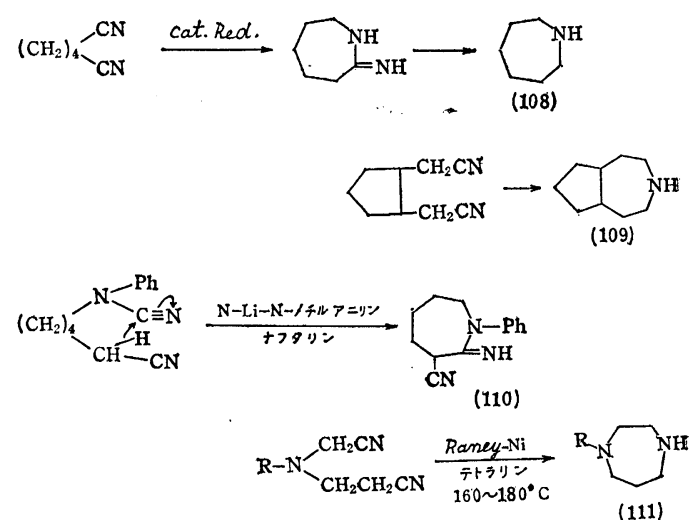

(111)

これらとは異なる反応であるが Gardent ${ }^{86)}$ は 1,2-ジ シアノメチルベンゼンに $\mathrm{HBr}$ を作用させて (112) を合 成している。

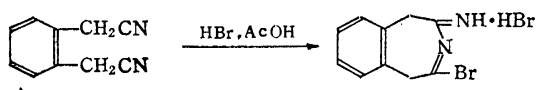

(112)

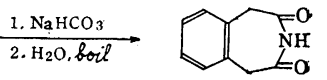


Friedel-Krafts 法としては Cagniant ら ${ }^{87)}$ は (113) を, Fontaine ら ${ }^{88)}$ は (114)を, Renson ${ }^{89)}$ は (115)を, ここに入れるべき方法でないが Braun ${ }^{90)}$ は (116)を, Kanaoka ら ${ }^{91}$ は (117) を合成している。
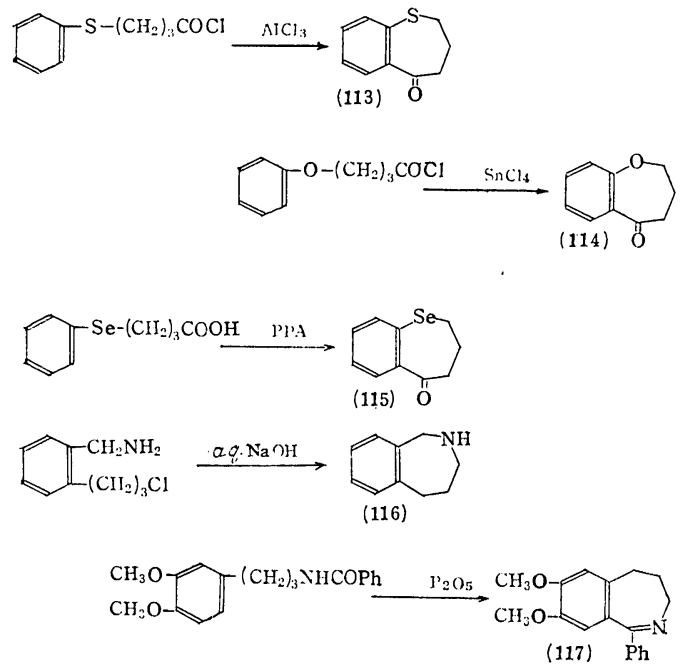

\section{II. その他の方法による合成}

ここでは前章以外の合成法で主に単環で窒素, 酸素, 硫黄を含む化合物について述べる。ただし前章で書きも らしたもの，ベンゼン環を縮合したものも少し含む。

1. 含空素環化合物 Paquette ${ }^{92)}$ は 2,4,6-トリメ チルフェノールのナトリウム塩にクロルアミンを作用さ せ て, 3,5,7-trimethyl-dihydroazepin-2(3H)-one(118) を合成し，N.M.R. などで式を推定している。

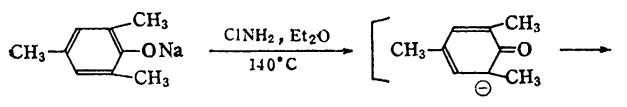

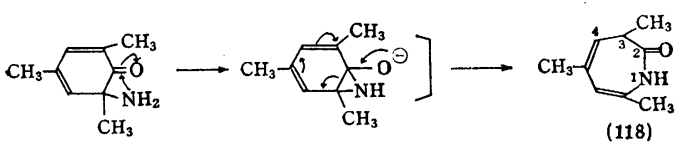

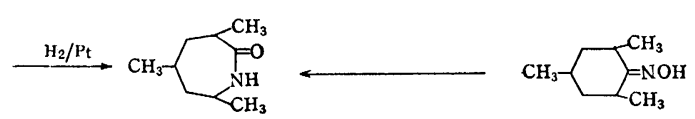

(118)
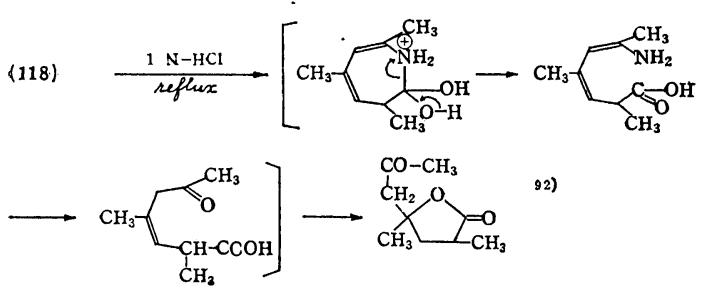

（118）に光をあてると（120）または（120'）になる が, $\mathrm{C}_{3}-\mathrm{H}$ の $\mathrm{C}_{4}-\mathrm{H}$ の N.M.R. 結合次数が $\mathrm{J}=-9.8 \mathrm{cps}$ という值を示すことから cis 配置であることがわかり (120）式が主であることを示している。このことからも との（118）も（119）式が主であると思われる ${ }^{932 。}$
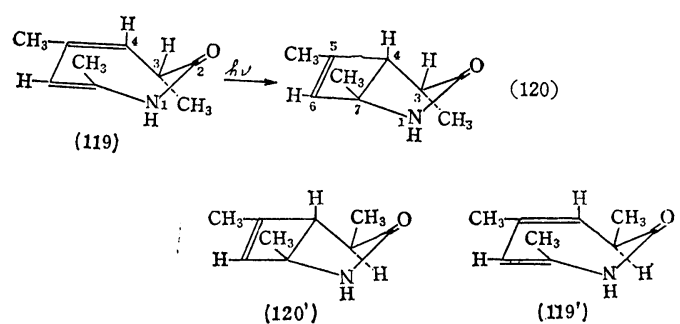

（119）にアセチレンジカルボン酸, テトラシアノエチ レンを作用させると，1，4-付加をするが， perfluorobutine はつぎのような付加物をあたえる。無水マレイ ン酸とは付加しない(94)。

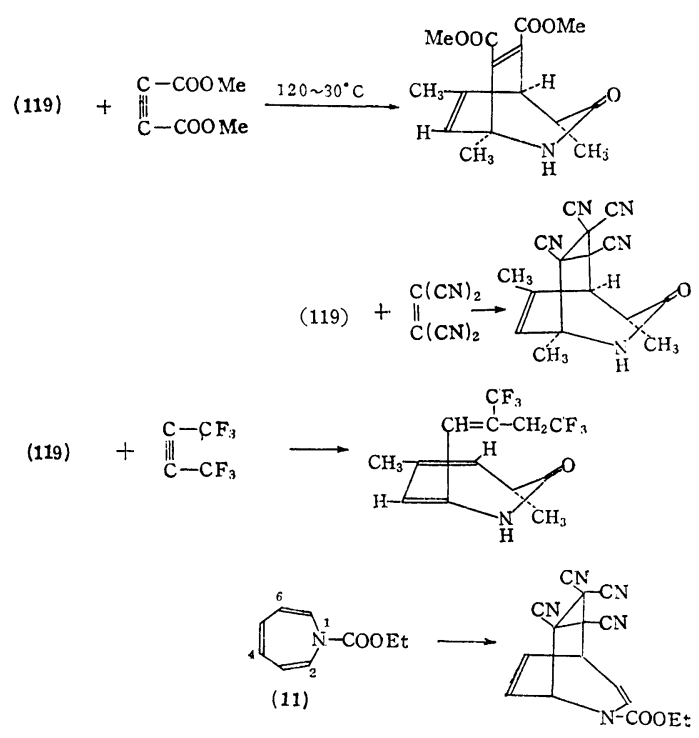

Baldwin ら, Hende ら, Kende ら ${ }^{94)}$ (11) では Hafner ら ${ }^{94)}$ のよな 2,6 ではなく2,4-二重結合で付 加をすること，およびその付加物のブロム化について報 告している。N-メチル-(118) を還元してえた（121） に光をあてると (122) と（123）が 6:1 でできること から，もとの (118) には (119) と (119') の平衡が存 在するが $\left(119^{\prime}\right)$ が 少ないことが考えられる年。

(118) $\frac{1 . \mathrm{NaH}}{2 . \mathrm{CH}_{3} 1}$

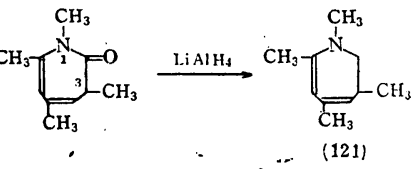




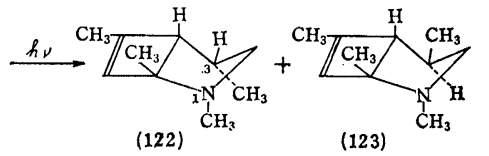

Wolff(95) は 1912 年フェニールアジドとアニリンを加 熱して (124) をえているが式を確定していない。しかし

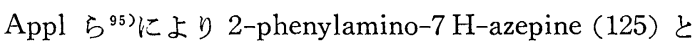
推定された。またアニリンのかわりに数種のアミンを反 応させたものもえている。I.R. 吸収は $1582 \mathrm{~cm}^{-1}$ に共 役 $\mathrm{C}=\mathrm{N}$ の吸収があること，一般にアミジン形の方が安 定であることなどにより(125) 式をとっているものと思 われる。
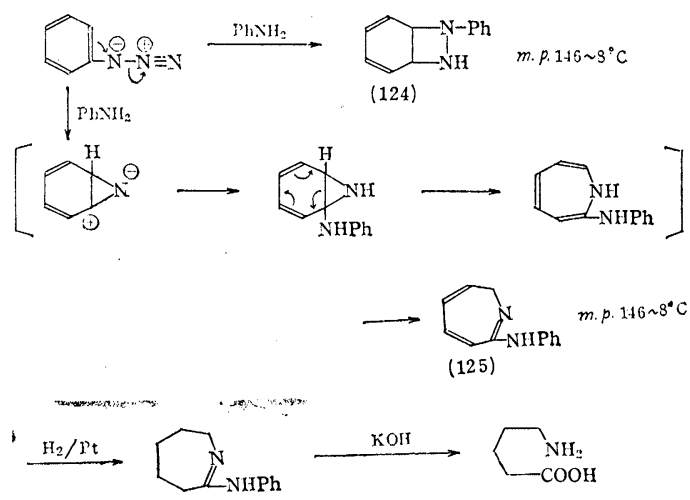

非共役 $\mathrm{C}=\mathrm{N}+1623 \mathrm{~cm}^{\prime}$

その他前章で書き残したものをつぎに 2,3 畵いてお く。Lyle ら ${ }^{96}$ は (126) を, Ebnöther ら ${ }^{97)}$ は (127) を 微量えている。その他 $(128)^{98)},(129)^{99)},(130)^{100)},(131)$ ${ }^{101)},(132)^{102)}$ なども合成されている。
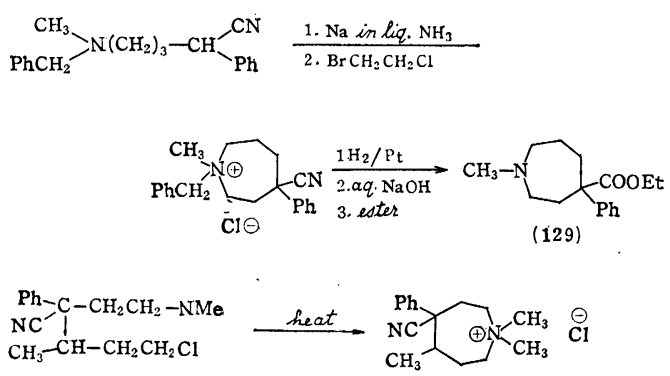

(130)

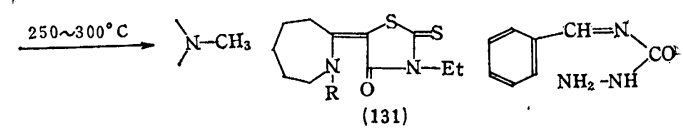<smiles></smiles>

(132)

2. 含酸素環化合物 1-3で 2,3 ののについて書 いたが，それ以外のものについてつぎに書く。

Vogel ら ${ }^{103)}$ は 1,2-dimethyl-4-cyclohexene-1,2-oxide の臭素付加物を脱臭化水素することにより 2,7-dimethyloxepin (133) をえ，さらに 1965 年 oxepin を合成 している。Sondheimer ら ${ }^{104)}$ は同じ方法で benzo[b] oxepin (134) や (135) なる $10 \pi$ 電子系の非ベンゼン系 芳香族化合物と思われる物翼をえている。
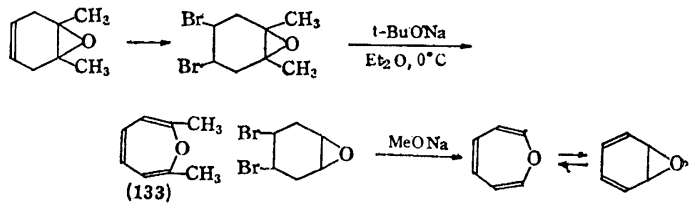
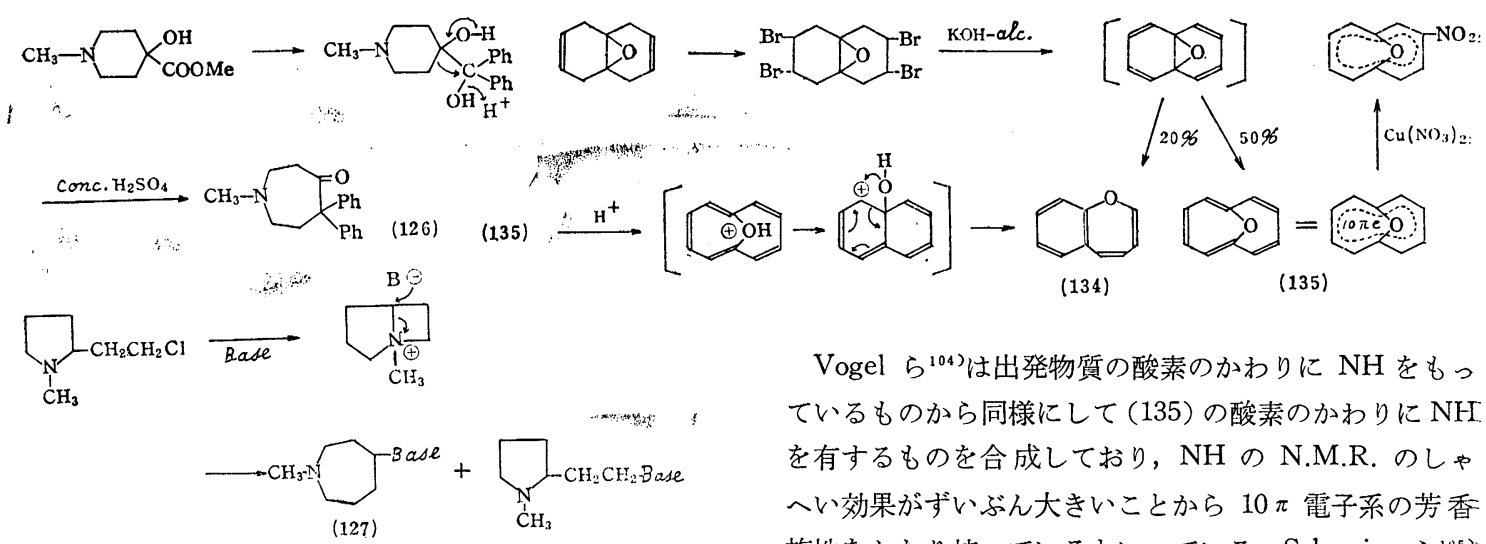

$\left(\mathrm{CH}_{2}\right)_{6}^{-}-\mathrm{NH}_{2}+\left(\mathrm{CH}_{2}\right)_{-}^{-}-\mathrm{OH} \frac{\text { Raney } \mathrm{Ni}}{\text { in alc. heat }} \square \mathrm{NH}^{-}\left(\mathrm{CH}_{2}\right)_{4} \mathrm{OH}$

(128)

Vogel ら ${ }^{(04)}$ は出発物質の酸素のかわりに $\mathrm{NH}$ をもっ ているものから同様にして (135) の酸素のかわりにNH を有するものを合成しており，NH の N.M.R. のしゃ へい効果がずいぶん大きいことから $10 \pi$ 電子系の芳香 族性をかなり持っているといっている。Schweizer ら ${ }^{105) *}$ はジヒドロピランにクロールカルベンを作用させて (136) をえている。Braun ${ }^{106)}$ はアクロレインからこの 
異性体 (136') をえている。Paquette ら ${ }^{107)}$ は (136) に 光をあてて (137) をえている。

$$
\begin{aligned}
& \text { OI } \frac{\mathrm{CH}_{2} \mathrm{Cl}_{2} \mathrm{BuLi}}{\text { in Heptanc }} \bigcap_{\mathrm{C}}^{\mathrm{Cl}} \stackrel{150^{\circ} \mathrm{C}}{\longrightarrow} \\
& \sum_{(136)} \stackrel{h \nu}{\longrightarrow} \\
& \mathrm{CH}_{2}=\mathrm{CHCHO} \frac{\mathrm{Zn} / \mathrm{Cu}^{+}}{\mathrm{AcOH}}{ }_{\mathrm{HO}}^{\mathrm{HO}}-\frac{\mathrm{Et}_{2} \mathrm{CO}_{3}}{\mathrm{~K}_{2} \mathrm{CO}_{3}}
\end{aligned}
$$

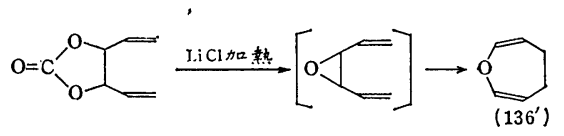

さらに Meinwald ら ${ }^{108)}$ はつぎの方法その他で (136) をえておりり，テトシアノエチレンと 2,4 の二重結合間 で付加をすることを報告している。

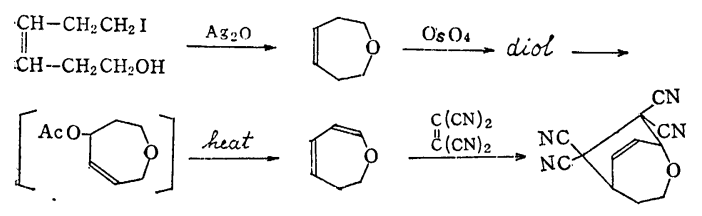

Quin ら ${ }^{109)}$ はつぎの方法で（138）を合成している。

Criegee $^{110)}$ は (139) を, Schweizer ら ${ }^{111}$ は (140) を, Zaugg ら を合成している。
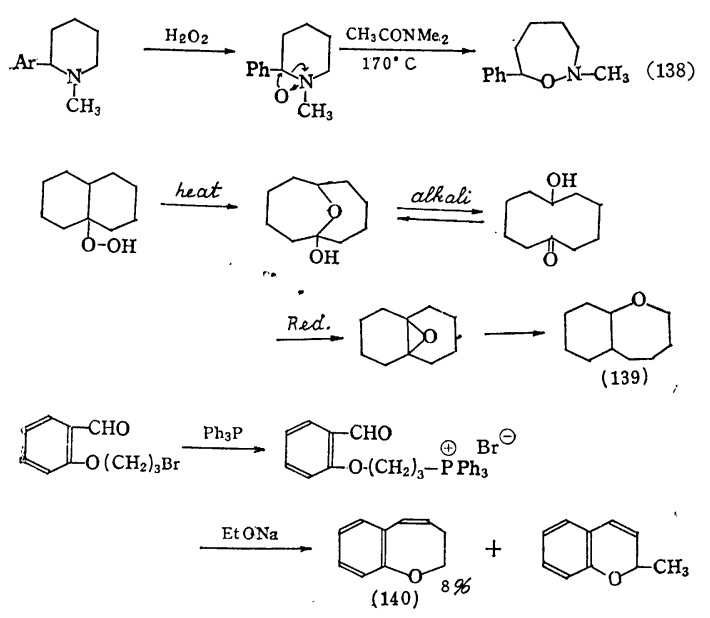<smiles>CN1CCN(C2([14CH3])CCOc3ccccc32)CC1</smiles><smiles></smiles>

(142)

3. 含イオウ環化合物 Fromm ら ${ }^{114}$ は (143) を,
Arndt ら ${ }^{115}$ は（144）と思われるものを合成したと報告 しているが, Bezzi ら ${ }^{116)}$ は (144) はX線解析の結果七 員環でなく (145) 式のような共役系化合物であると報告 しているがまだ疑いがあるようである。

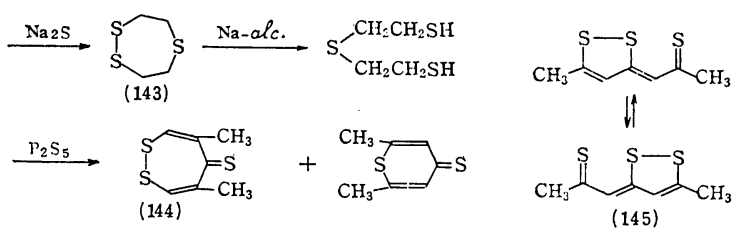

Traverso $^{117)}$ はつぎの方法で 1,2-dithiepane-5-one (146)を, Schöberl ら ${ }^{118)}$ は 1,2-thiepane (147) を, Tucker ら ${ }^{119)}$ その他は 1, 4-dithiepan-6-ol を, Oae ${ }^{120)}$ は 1,3-dithiepane などを報告している。

$$
\begin{aligned}
& S=0 \stackrel{\mathrm{P}_{2} \mathrm{~S}_{5}}{\longrightarrow} S=\mathrm{S} \frac{1 \mathrm{HgCl}_{2}}{2 \mathrm{Na}_{2} \mathrm{CO}_{3}} \stackrel{S}{\mathrm{~S}}=0 \\
& \left(\mathrm{CH}_{2}\right)_{\mathrm{m}_{\mathrm{CH}_{2} \mathrm{SH}}}^{\mathrm{CH}_{2} \mathrm{SH}} \stackrel{\mathrm{FeCl}_{3}}{\longrightarrow}\left(\mathrm{CH}_{2}\right)_{\mathrm{CH}_{2}-\mathrm{S}}^{<\mathrm{CH}_{2}-\mathrm{S}}
\end{aligned}
$$

Howard $^{121)}$ は (148) を, Wagner ${ }^{122)}$ は (148) から 5, 6-dihydro-3-trifluoromethyl-8 $\mathrm{H}$-1, 4-dithiepino $[3,2$ -CJpyrazole (148') をえている。Boberg ${ }^{123)}$ は (149) な どを，Wynberg ${ }^{124)}$ は (150) を報告している。

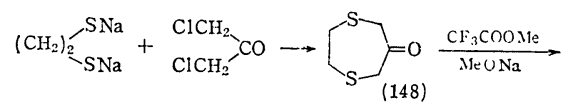

$$
\begin{aligned}
& \sum_{\mathrm{S}}^{\mathrm{S}}=\mathrm{COCF}_{3} \frac{\mathrm{NH}_{2} \mathrm{NH}_{2}}{\mathrm{AcOH} \text { alc. }}
\end{aligned}
$$

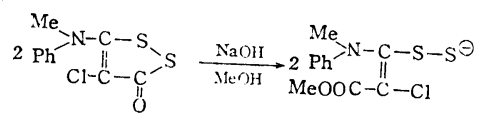

$$
\begin{aligned}
& \longrightarrow \mathrm{MeOOC}_{\mathrm{S}-\mathrm{S}}^{\mathrm{Ph}^{-}-\mathrm{N}} \prod_{-\mathrm{N}}^{\mathrm{CH}_{\mathrm{Ph}}}-\mathrm{S} \text { atc. }
\end{aligned}
$$

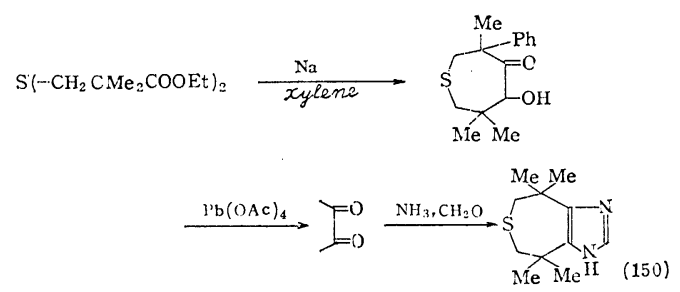

Truce ら ${ }^{125)}$ は benzo[d]thiepin dioxide (151) を合 成したが，芳香族性が少ないといっている。 


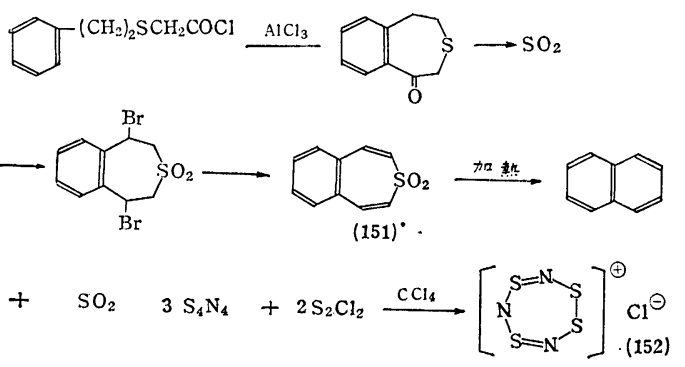

Meuwsen $^{126)}$ その他は窒化イオウと塩化イオウを反応 させて (152)をえている。X線解析の結果この式をとっ ているらしい。また Eglinton ら ${ }^{127)} は$ (153) を合成し, その式を N.M.R. などで推定している。

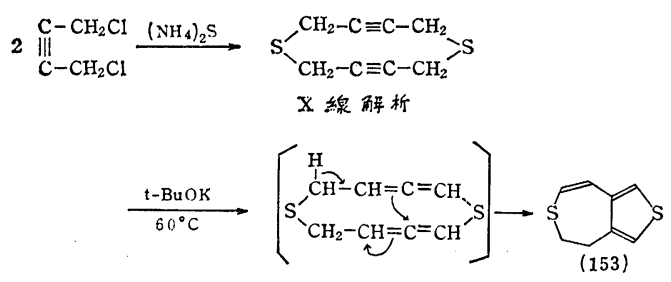

その他 $(154)^{128)},(155)^{129)},(156)^{130)},(157)^{131)},(158)$ ${ }^{132)},(159)^{133)},(160)^{134)},(161)^{135)}$ などが報告されてい る。また Milligan ら ${ }^{136)}$ は bunte 塩 (162) から (163) を合成している。

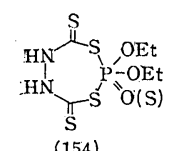

(154)<smiles>O=C1CSc2ccccc2N1</smiles>

(157)<smiles>O=C1CCCCC1N1CCCCC1</smiles><smiles>O=C1CSCCc2c1ccc1ccccc21</smiles><smiles>O=C1Nc2ccccc2CS1</smiles>

(158)

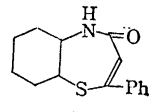

(159)

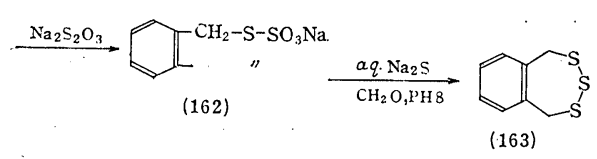

\section{III. その 他}

乱雑に書いてしまいベンゾアゼピン類, ジベンゾアゼ ピン類などが残ったところで紙面が無くなってしまった のでつぎにごく一部分の式と文献を書いておく。
$(65,66 \text { など })^{197)}$<smiles>Cc1sc(C)c(C)c(=O)c1C</smiles>

138)<smiles>[R]c1ccc2c(c1)NC(=O)c1ccccc1N2</smiles><smiles></smiles><smiles></smiles><smiles>C1CCN2CCCC2C1</smiles>

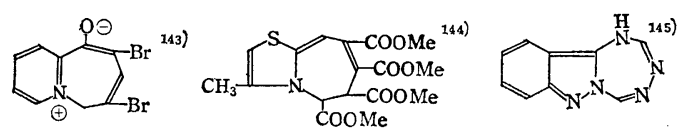

以上で Chemical Abstracts 63 巻までの文献の主な るものについて，ごく簡単に書いたが，筆者の不才と当 大学には原報の雑誌が少ないのでかなり間違ったことを 書いたことと思われるがお許しをこい筆を置く。

(昭和 41 年 3 月 14 日受理)

\section{文献}

*) “Rodd's Chemistry of Carbon Compounds"(初) 版) 4-C 1581 (1960)

1) O. Wallach, Ann. 312187 (1900); R.K. Hill et al., J. Am. Chem. Soc. 875646 (1965); G. A. Grob et al., Helv. Chim. Acta 461190 (19 63)

2) J.G. Lombardino et al., USP 3,045,008; C.A. 5716640

3) T. Hoshino, Y. Iwakura, Chem. Highpolymer $s$ (Japan) 2280 (1945)

4) D. Misiti et al., Tet. Letters 1965 1071; C.A. 6216191 ; K. Mitsuhashi et al., Chem. Pharm. Bull. (Tokyo) 13951 (1965)

5) L. Birkofer et al., Chem. Ber. 952212 (1962)

6) S.C. Dieckman et al., J. Org. Chem. 14530 (1949) ; A.H. Sommers et al., J. Am. Chem. Soc. 765805 (1954); S.M. McElvainet et al., ibid. 761126 (1954)

7) K. Hohenlohe-Oehringen, Monatsh. Chem. 96 257 (1965); C.A. 6214683 (1965)

8) L.H. Briggs et al., J. Chem. Soc. 1937456 ; R.T. Conley, J. Org. Chem. 23 1330 (1958); S. Uyeo et al., Chem. Pharm. Bull. (Tokyo) 131084 (1956)

9) I.L. Knunyants et al., Doklady. Akad. Nauk. S.S.S.R 68523 (1949); C.A. 441469 (1950)

10) E. Imoto et al., 日化 83343 (1962)

11）日特 11394 C.A. 6113332 (1964)

12) K. Hafner et al., Angezv. Chem. 7580 (1963); C.A. 59 1590; Tet. Letters 1964 1733; C.A. 618277 ; W. Lwowski et al., J. Am. Chem. Soc. 85 1199, 1200 (1963); K. Hafner, Angew. Chem. (International) 3165 ; R.J. Cotter et al., J. Org. Chem. 29751 (1964)

13) F.D. Marsh et al., J. Am. Chem. Soc. 873529 (1965) 
14) C.G Overberger et al., ibid. 781967 (1956); N.J. Leonard et al., J. Org. Chem. 281957 (i963)

15) S. Morosawa, Bull. Chem. Soc. Japan 31418 (1958); 331108 (1960)

16) ibid. 331118 (1960); 36599 (1963)

17) E. Vogel et al., Angerv. Chem. 7476 (1962) ibid. (international) 1 53; Ann. 6821 (1965)

18) E. Vogel, Ann. 644172 (1961); Anger Chem. 724 (1960); ibid. (International) 21 (1963); W.R. Roth et al., ibid. 2115

19) E.L. Stogryn et al., J. Org. Chem. 291275 (1964); 3088 (1965)

20) E.E. Schweizer et al., J. Am. Chem. Soc. 82 4085 (1960)

21) S. Masamune et al., Chem. Ind. (L) 1965184 ; C.A. 627725 (1965)

22) E. Bullock et al., Proc. Chem. Soc. 1962 122; J. Am. Chem. Soc. 842260 (1962)

23) P.J. Brignell, E. Bullock, A.W. Johnson, $J$. Chem. Soc. 1963 4819; 19641632

24) E. Benary, Ber. 532218 (1920)

25) P.J. Brignell et al., J. Chem. Soc. 19654226

26) A.W. Johnson et al., Chem. Comonmun. 1965 95 ; C.A. 62 16184; Proc. Chem. Soc. 1964 $263 ;$ J. Chem. Soc. 19652411

27) J.A. Moore et al., J. Am. Chem. Soc. 773417 (1955); 816026 (1959); 843022 (1962); $J$. Org. Chem. 29 2124, 2128 (1964)

28) J.A. Moore et al., ibid. 30 1887, 1889 (1965); Chem. Commun 1965, 468 C.A. 63 16354; Trans. N.Y. Acad.Sci. 27591 (1965); C.A. 63 13263; J. Org. Chem. 31 34, 42, 48, 52 (1966)

29) L.H. Sternbach et al., J. Org. Chem. 26.1111 4936, 4488 (1961) S.C. Bell et al., ibid. 27 562, 1691 (1962); L.H. Sternbach et al., ibid. 3781, 3788 (1962) ; USP 3051701; C.A. 5711641 (1962)

30) L.H. Sternbach et al., J. Org. Chem. 304267 (1965)

31) E.D. Bergmann et al., ibid. 25827 (1960); Israel J. Chem. 1125 (1963); C.A. 607997

32) O. Hinsberg et al., Ann. 287220 (1895)

33) J. Thiele et al., Ber. 40955 (1907)

34) C.A.C. Haley et al., J. Chem. Soc. 1951 3155; I.L. Finar, ibid. 19584094 S.B. Vaisman; C. A. 345847 (1940) 38750 (1944)

35) J.A. Barltrop et al, J. Chem. Soc. 1959 1132; J.O. Holford et al., J. Am. Chem. Soc. 853354 (1963)

36) D. Lloyd et al., J. Chem. Soc. 19653785

37) F.E. King et al., ibid. 1952 2144; W.H. Stafford et al., Chem. \& Ind. 1956 765; C.A. 51 2819 (1957) ; J.A. Barltrop et al., ibid. 1957466

38) W. Ruske, J. Prakt. Chem. 18173 (1962); C.A. 584576 (1963)
39) H.D. Stackel, Chem. Ber. 952172 (1962)

40) $W$. Ried et al., ibid. 871801 (1954); 92 2902: (1959)

41) G. Schwartzenbach et al., Helv. Chim. Acta 231139 (1940); D. Lloyd et al., J. Chem. Soc. 1956 2597, 1958 118; B. Eistert et al., Chem. Ber. 93264 (1960) ; R.P. Bell et al., J. Chem. Soc. 19642195

42) H.A. Staab, F. Vögtle et al., Chem. Ber. 98 2681, 2701, 3479 (1965)

43) W. Tochtermam, Tet, Letters 19642981

44) G.B. Backman et al., J. Am. Chem.Soc. 71 1985 (1949); W. Ried et al., Chem. Ber. 86 1101 (1953); 90 815, 825, 828 (1957); 922932 (1959); E. Fancher et al., USP 3021325, C.A. 574687 (1962)

45) B.P 858558, C.A. 5517672 (1961)

46) Ger. P 1047785; C.A. 554552 (1961)

47) G.O. Dudek et al., J. Am. Chem. Soc. 832099 (1961)

48) C.M. Hofmann et al., J. Org. Chem. 273565 (1962)

49) M. Weissenfels, J. Prakt. Chem. 20 117; C.A. 598756 (1963)

50) K.W. Merz et al., Naturrvissenschaften 50663 (1963); C.A. 604148 (1964); BP 822215; C. A. 5411062 (1960)

51) R.M. Acheson et al., J. Chem. Soc. 1948 1366; 19564727

52) J. Chapman et al., ilid. 1949 1638; I.J. Pachter et al., J. Org. Chem. 15909 (1950)

53) G. Losse et al., Chem. Ber. 90257 (1957); 91 150 (1958)

54) J.D. Loudon et al., J. Chem. Soc. 1963 5496; 1964591

55) C.G. Overberger et al., J. Am. Chem. Soc. 71 2661 (1949); 743290 (1952); 784470 (1956); 802317 (1958) ; 81217 (1959); M. Lipp et al., Ann. 618110 (1958)

56) G. Zinner et al., Arch. Pharm. 295526 (1962); C.A. 584577 (1963)

57) S. Huenig et al., C.A. 614307 (1964)

58) W. Ried et al., Angew. Chem. 75476 (1963); C.A. 597531 (1963); Ann. 666 113, 135 (1963); 681 45, 52 (1965)

59) P.M. Maitlis, Proc.Chem. Soc. 1957354

60) L.K. Mushkalo, C.A. 5318057 (1959)

61) T. Haga, R. Majima, Ber. 36333 (1903)

62) P. Oxley et al., J. Chem. Soc. $1947497 ; 1950$ 862 ; A.F. Mckay et al., J. Am. Chem. Soc. 70 430, 3990 (1948); R. Paul, G.W. Anderson et al., J. Org. Chem. 263347 (1961)

63) R.N. Johnson et al., ibid. 273958 (1962)

64) R. Paul et al., ibid. 263347 (1961)

65) St. von Niementowski, Ber. 343330 (1901):: P.A. Labriola, J. Org. Chem. 5329 (1940) 
66) A.E.S. Fairfull et al., J. Chem. Soc. 195247 08 ; A.E. Blood et al., J. Org. Chem. 22873 (1957); C.A. 52404 (1958)

67) Ya. A. Levin et al., Zhur Obshckei Khim. 31 1573 (1961); C.A. 5522336 (1961); W. Ried et al., Chem. Ber. 95459 (1962); 971214 (19 64); 98 3523, 3532 (1965)

68) K. Dimroth et al., ibid. 892602 (1956); 90 1628 (1957); 983907 (1965)

69) ibid. 90 1623; Angew. Chem. 68518 (1956); 6995 (1957); A. Schönberg et al., J. Org. Chem. 23104 (1958)

70) K. Dimroth et al., Angew. Chem. 73436 (19 61) ; C.A. 5525977 (1961)

71) R. Huisgen et al., Chem. Ber. 9118 (1958); M.J. Jorgenson, J. Org. Chem. 273224 (1962)

72) K. Hafner et al., Angew. Chem. 71672 (19 59) ; C.A. 546572 (1960)

73) ibid. Angew. Chem. (International) 2123 (19 63)

74) W. Triebs et al., J. Prakt. Chem. 14208 (19 61) ; C.A. 5610098 (1962)

75) A.H. Rees, J. Chem. Soc. 19651749

76) G. Westöö, Acta Chim. Scond. 13604 (1959); C.A. 553609 ; 16776 (1962); C.A. 578847

77) A. Yokoo, S. Morosawa, Bull. Chem. Soc. Japan. 29631 (1956); A.F. Casy, J. Pharm. Pharmacol. 17157 (1965); C.A. 63579 (1965)

78) B.D. Astill et al. J. Am. Chem. Soc. 774079 (1955)

79) G.R. Proctor, J. Chem. Soc. 1957 2312, 2302 19613989

80) N.J. Leonard et al., J. Am. Chem. Soc. 7631 93 (1954)

81) S.M. McElvain et al., ibid. 551233 (1933)

82) W.H. Bell et al., J. Chem. Soc. 19644926

83) P. Ruggli et al., Helv. Chim. Acta 181388 (1935) ; J.O. Halford et al., J. Org. Chem. 17 1276 (1952)

84) H.J. Hitzschke et al., C'ıem. Ber. 871635 (19 54)

85) A. Kotelko, Acta Polon. Pharm. 19 109, 215 (1962); C.A. 597370 (1963)

86) J. Gardent, Compt. Rend. 2594724 (1964); C.A. 6211779 ; USP 3205222 ; C.A. 6313226 (1965)

87) P. Cagniant. et al., Compt. Rend. 223677 (19 46); W.E. Trace et al., J. Am. Chem. Soc. 74974 (1952)

88) G. Fontaine et al., Compt. Rend. 229889 (19 49)

89) M. Renson, Bull. Soc. Chim. Belges. 73 483; C.A. 618278 (1964)

90) J.V. Braun et al., Ber. 56690 (1923)

91) Y. Kanaoka et al., Tet. Letters 19642419 ; C. A. 6113281 (1964)
92) L.A. Paquette, J. Am. Chem. Soc. 844987 (1962); 853288 (1963)

93) O.L. Chapman et al., 86498 ; L.A. Paquette, ibid. 86500 (1964)

94) L.A. Paquette, J. Org. Chem. 293447 (1964); J. Am. Chem. Soc. 864092 (1964); K. Hafner et al., Angew. Chem. 751041 (1963); J.E. Baldwin et al., J. Am. Chem. Soc. $87 \quad 4819$ (1965) ; A.S. Kende et al., ibid. 87 5044; J.H. Van Den Hende et al., Chem. Commun. 1965 384 ; C.A. 6314674

95) vonL Wolff, Ann. 39459 (1912); M. Appl et al., Chem. Ber. 91 1, 12 (1958); 922961 (1959)

96) R.E. Lyle et al., J. Am. Chem. Soc. 763536 (1954)

97) A. Ebnöther et al., Helv. Chim. Acta. 47745 (1964)

98) R G Rice et al., J. Org. Chem. 231352 (19 58); C.A. 5317885 (1959)

99) 日特 13828

100) W F Bruce et al., B P 843924; C.A. 552705 (1961)

101) B P 814375; C A 566827 (1962)

102) A. Rosenthal et al., Can. J. Chem. 42 956. (1964) ; C.A. 6015771 (1964)

103) E. Vogel et al., Angew. Chem. 76535 (1964); C.A. 615611 (1964); Tet. Letters 1965609 ; C.A. 63578 (1965)

104) F. Sondheimer et al., J. Am. Chem. Soc. 86 3168 (1964); E. Vogel et al., Angew. Chem. (Internationol) 3 510,642 (1964); Tet. Letters 1965: 3613

105) E.E. Schweizer et al., J. Am. Chem. Soc. 82 4085 (1960)

106) R.A. Braun, J. Org. Chem. 281383 (1963)

107) L.A. Paquette et al., J. Am. Chem. Soc. 87 3417 (1965)

108) J. Meinwald et al., ibid. 803132 (1958); 82 4087 (1960)

109) C.D. Quin et al., J. Org. Chem. 303035 (19 65)

110) R. Criegee, Ber.77 22, 722 (1944)

111) E.E. Schweizer et al., Tet. Letters 1963979 ; C.A. 599980

112) H.E. Zaugg et al., USP 3122551 ; C.A. 611844 (1964)

113) P. Cagniant, Compt. Rend. 229889 (1949)

114) E. Fromm et al., Ber. 58308 (1925)

115) F. Arndt et al., Ber. 58 1636(1925); Chem. Ber. 89 124, 730 (1956); Ann. Chim. Rome 43: $795 ; 441027 ; 45$ 689, 694 (1955)

116) B. Bezzi et al., Nature 182247 (1958)

117) G. Traverso, Chem. Ber. 911224 (1958)

118) A. Schöberl et al., Angew. Chem. 69713 (19 57); Ann. 61466 (1958)

119) N.B. Tucker et al., J. Am. Chem. Soc. 55775 
(1933); W. Autenrieth et al., Ber. 321375 (18 99) ; R.C. Fuson et al., J. Am. Chem. Soc. 71 823 (1949)

120) S. Oae et al., Tetrahedron 20417 (1964); $C$. A. 6014371 (1964)

121) E.G. Howard, J. Am. Chem. Soc. 82158 (19 60)

122) H.A. Wagner, USP 3158619 ; C.A. 627784 (1965)

123) F. Boberg, Ann. 683146 (1695)

124) H. Wynberg et al., Chem. Commun. 1965171 C.A. 635630 (1965)

125) W.E. Truce et al., J. Am. Chem. Soc. 78848 (1956)

126) A. Meuwsen, Ber. 651724 (1932); 化学の領域 19774 (1965)

127) G. Eglinton et al., J. Chem. Soc. 19641154

128）日特 $17211 ;$ C.A. 5911254 (1963)

129) G. Gignarella et al., J. Am. Chem. Soc. 82 1596 (1960); BP 898850; C.A. 5713784 (19 62) ; USP 3051727; C A 583450 (1963)

130) C.W. Whitehead et al., J. Org. Chem. 28743 (1963)

131) F. Jakob et al., Chem. Ber. 9688 (1963)

132) Neth. Appl. 6402756 ; C.A. 629158 (1965)

133) J. Krapcho, USP 3075968 ; C.A. 595181 (19 63)

134) F.K. Kirchner et al., J. Am. Chem. Soc. 81 1721 (1959); N. YaKozlova et al., Ukr. Khim. Zh. 28960 (1962); C.A. 59 6410;Zh. Obshch. Khim. 342282 ; C.A. 61 8264,11960; J. Krapchn; USP 3075967 ; C.A. 59 6423; J. Med. Chem. 6544 (1963); C.A. 5812816 (1963); USP 3089872 ; C.A. 5911541

135) P. Cagniant et al., Bull. Soc. Chim. France 1961 1931; 196219313 C.A. 55 27364, 5612845

136) B. Milligan et al., J. Chem. Soc. 19652901

137) M. Gordon, C.A. 604147 (1964); B P 956592; C.A. 618328 (1964); L.H. Sternbach et al., Helv. Chim. Acta 452226 (1962); 461720 (1963); J. Org. Chem. 282456 (1963); Ger. P 1145625; C.A. 59 10056; Belg. P 620020; C.A. 598768 (1963) ; J. Org.Chem. 274675 (19 62); USP 3131178; C.A. 614383 (1964); J.
Org. Chem. 272795 (1962) ; R. Littell et al., J. Med. Chem. 8892 (1965); C.A. 6318087 (1965); T.S. Sulkowski, USP 3176008 ; C.A. 6216284 (1965); S.C. Bell et al., F P 137834 3; C.A. 6210454 (1965); L.H. Sternbach et al., J. Org. Chem. 283013 (1963); Neth. Appl. P. 6407796 ; C.A. 631808 (1965); F.H. McMillan et al., FP 1394287 ; C.A. 638387 (1965) ; S.C. Bell et al., C.A. 5712494 (1962); L.H. Sternbach et al., Belg. P 619101; C.A. 5910092 (1963); USP 3100770; C.A. 601780 (1964); USP 3182065 7 ; C.A. 63 2990, 5662, 7042 (1965); Belg. P 646617 ; C.A. 6314889 (1965); R. Littell et al., J. Med. Chem. 8722 ; C.A. 6314837 (1965)

1.38) M. Protiva et al., C.A. 579817 ; Czech. $P$ $105590 ;$ C.A 59 10010; 107631 2 C.A. 6017 18; C.A. 598702 (1963); F. Gadient et al., Helv. Chim. Acta 451860 (1962)

139) F. Hunziker et al., C.A. 59 8753(1963); Helv. Chim. Acta 462337 (1963); 471163 (1964); A.R. Hanze et al., C.A. 601756 (1964); FP 1334944 ; C.A. 613126 (1964); W. Ried et al., Chem. Ber. 92949 (1959)

140) BP 802901 ; C.A. 55592 (1961); J. Jaques et al., Helv. Chim. Acta 421265 (1959); K. Hoffmann et al., Ger. $P$ 1062246, C.A. 55 26001 (1961); C.A. 56 488; H.L. Yale et al., C.A. $58540 ; 5911542$; R. Quelet et al., Compt. Rend. 2581251 (1964); C.A. 6010685 , J.D. Loudon et al., J. Chem. Soc. 1957 3818; $19581568 ; 1959885$; C.I. Brodrick et al., ibid. 19543857 ; C.A. 618328 (1964)

141) K.F. Schmidt et al., DRP 427858, 439041; J. V. Braun et al., Ber. 63 507 (1930); R. Huisgen et al., Ann. 61065 (1957)

142) N.J. Leonard et al., J. Am. Chem. Soc. 7130 $89 \sim 3098$ (1949); K. Schöfield et al:, Chem. Ind. $1963572 ;$ C.A. 591587

143) A. Fozard et al., J. Org. Chem. 301523 (19 65)

144) D.H. Ried et al., C.A. 619486

145) G.S. Sidhu et al., C.A. 604149 ; 635649 